\title{
3D SEISMIC INTERPRETATION AND STRUCTURAL ANALYSIS OF SITRA-8 FIELD IN ABU GHARADIG BASIN, NORTHERN WESTERN DESERT, EGYPT
}

\author{
El-Kharboutly, K. F. ${ }^{1}$, Helal, A. M. A. ${ }^{2}$, and Aly, S. A. ${ }^{2}$ \\ 1- General Manager at Petro-Amir Oil Company, Cairo, Egypt. \\ 2- Geophysics, Department of Geophysics, Faculty of Sciences, Ain Shams University, Cairo, Egypt.
}

\begin{abstract}
Sitra-8 Field which located in the northern Western Desert of Egypt is famous with its multi-reservoir zones. The real problem in this field is the hydrocarbon migration which cause in turn that some of the wells in the area became water bearing or even dry. The integration between the structural elements deducted from the 3D seismic analysis and the litho-facies core data, as well as well logging interpretation, gave a clear vision about the water bearing reservoirs (Salama et al., 2017).

The present study proposes a significant integration between the subsurface geologic information, the interpreted 3D seismic data and the well logging data, for the purpose of delineating the major effective subsurface structures, as well as the reservoir evaluation at Sitra-8 Field area in the northern Western Desert of Egypt. This can be more helpful in any upcoming appraisal process in the future, which in turn will be reflected on the field development economically.

The study area lies between latitudes $29^{\circ} 44^{\prime} 41^{\prime \prime} \& 29^{\circ} 48^{\prime} 00^{\prime \prime} \mathrm{N}$ and longitudes $27^{\circ} 56^{\prime} 27^{\prime \prime} \& 28^{\circ} 00^{\prime}$ $00 "$ E. It covers an area about $35 \mathrm{~km}^{2}$. The authors in the current study tracked Abu Roash-C Member reservoir for the same problem and tried to introduce a suitable tool for addressing the hydrocarbon leaking problem. The study was a worthy challenge to find new promising areas; when it comes to the hydrocarbon exploration or development. The authors based on analyzing the petroleum system of the investigated area are recommending future drilling for development in the northeastern part of that area.
\end{abstract}

Keywords: 3D seismic Interpretation, Core data Analysis, Structural Interpretation and Reservoir Modeling, Sitra-8 Field, Abu Gharadig Basin.

\section{INTRODUCTION}

The abundance of oil and gas discoveries let the northern Western Desert be considered as a major petroleum province in Egypt. The hydrocarbon potentiality of the Western Desert has attracted the major standard oil company's interests. Although the continuous exploration activities, there are too many promising areas still undiscovered in the Western Desert. These areas need the detailed examination and the reliable testing by drilling.

Abu Gharadig basin is the most productive basin in the northern Western Desert, having an enormous hydrocarbon potentiality. It trends in the $\mathrm{E}-\mathrm{W}$ direction, having sediments varying in age from Late Jurassic to Early Cretaceous. The basin development of Abu Gharadig basin is restricted to the Upper Cretaceous, while the Upper Jurassic is in Gebel Rissu area to the East of the study area. The Lower Cretaceous development section is at Shushan and Shaltut basins to the North. Abu Gharadig basin covers an area of $17500 \mathrm{~km}^{2}$, Fig. (1). It is extends about $300 \mathrm{~km}$ from the East to the West and almost $60 \mathrm{~km}$ from the North to the South.

Abu Gharadig basin is a deep basin; the depth of the basement reaches down to $7.5 \mathrm{~km}$ (Abu El-Atta, 1990). The basin includes numerous mid basin arches which subdivide it into several sub-basins and they oriented NE-SW and they were believed to be related to the Syrian Arc folded belt (Schlumberger, 1995).

The present study proposed a significant integration between the subsurface geologic information, the interpreted 3D seismic data and the well logging data, for the purpose of delineating the major effective 
subsurface structures, as well as the reservoir parameters at Sitra-8 Field area in the northern Western Desert region of Egypt. This can be more helpful in any upcoming appraisal process in the future which in turn will be reflected on the field development economically.

Fig. 1: Abu Gharadig basin location, modified after, Abu-Hashish and Said (2016).

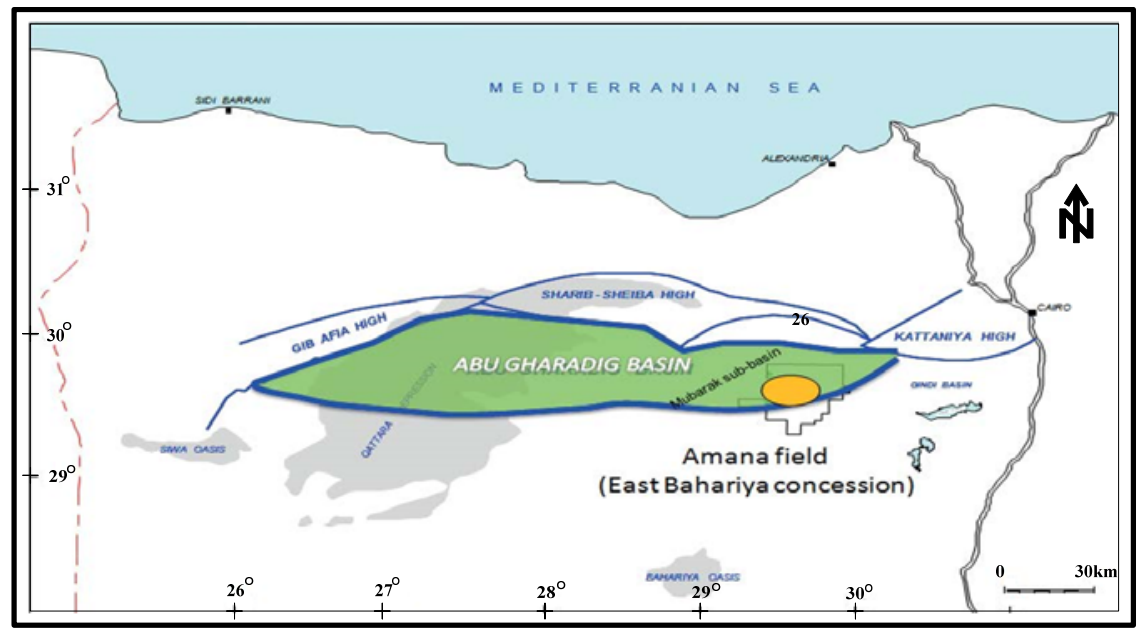

The present study proposed a significant integration between the subsurface geologic information, the interpreted 3D seismic data and the well logging data, for the purpose of delineating the major effective subsurface structures, as well as the reservoir parameters at Sitra-8 Field area in the northern Western Desert region of Egypt. This can be more helpful in any upcoming appraisal process in the future which in turn will be reflected on the field development economically.

The study area (SITRA - 8 Field) lies on the downthrown side of the main Abu Gharadig Basin border fault between the basin center and the Qattara High. Abu Gharadig Basin is occurred in the north-central part of the Western Desert of Egypt. It is bounded by the Kattaniya High to the East, by the Qattara High to the North and by the Sitra Platform to the South. The study area lies between latitudes $29^{\circ} 44^{\prime} 41^{\prime \prime}$ and

$29^{\circ} 48^{\prime} 00^{\prime \prime} \mathrm{N}$ and longitudes $27^{\circ} 56^{\prime} 27^{\prime \prime}$ and $28^{\circ} 00^{\prime} 00^{\prime \prime}$. E. It covers an area about $35 \mathrm{~km}^{2}$, Fig. (2).

In 1982, oil was discovered in Sitra 1-1 well and then it was found in Sitra 3-1 well in 1983 as well as in Sitra 5-1 in 1985. The Bed area blocks which are located to the north of Sitra-8 area (Bader El-Din Co. Concessions currently) have been discovered in 1993. As a result of these, Shell winning N. V. Egypt Company and obtained the development lease in Sitra Field. In addition, Sitra 4-1, Sitra 6-1 and Sitra 7-1 wells were found dry; they were drilled in 1985 and their leases were renounced. Another dry well was completed in 2000 and it is called C1-1.

The hydrocarbons appeared in the clastic rocks of Cretaceous age, in Abu Roash and Bahariya Formations. Kharita Formation is considered the primary reservoir in Bed-3 area in Abu Gharadig basin. Kharita Formation composed of fine to coarse grained sandstone, grayish shale and carbonates. Alam ElBueib Formation is the main reservoir in Qasr Field in Shushan basin; it composed of clastic rocks interceded with carbonates. It is also ranges in age from Lower Jurassic to Lower Cretaceous.

The total daily production in Sitra Field is 8000 (stb/d) recently. The production zones and their related total porosity are: Abu Roash- E Member (13-15 \%), Upper Abu Roash-G Member (15-16 \%), Lower Abu Roash-G Member (12 \%), Abu Roash-C Member (10-18 \%), Upper Bahariya Fm (9-11\%), and Lower Bahariya (8-9 \%).

\section{GEOLOGIC SETTING OF THE STUDY AREA}

The sedimentary section of the northern Western Desert ranges in age from Early Paleozoic to the Recent. Four major sedimentary cycles were recognized: Carboniferous, Late Jurassic, Middle and Late Cretaceous, and Middle Miocene. These cycles were marked by maximum southward transgression. Northward, there were maximum regressive phases occurred during the Triassic and the Early Jurassic, and continued in the Early Cretaceous, as well as in the Late Eocene (Schlumberger, 1984). 
3D seismic interpretation and structural analysis of Sitra-8 field

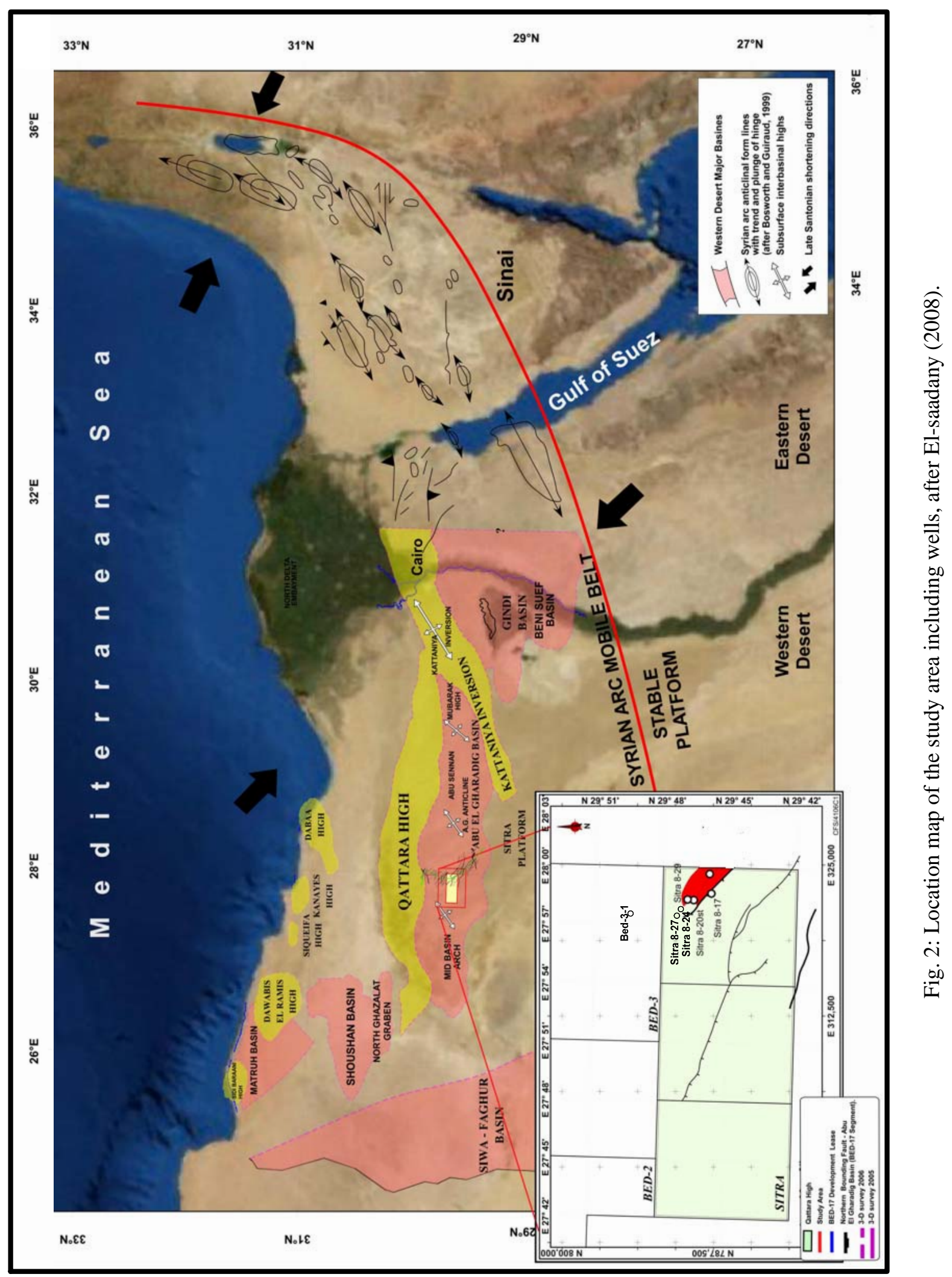


The Oligocene strata comprise a continuous succession of fine grained sediments cyclically interceded with sandy layers deposited in fluvial conditions. These sediments are representing the maximum regressive phase during the Oligocene in the Western Desert. The continuous exploration work in Abu Gharadig basin has defined its subsurface stratigraphic column. It is similar to the northern Western Desert stratigraphic section. The stratigraphic section is ranging from Paleozoic to recent time. It includes a group of marked formations illustrated from bottom to top, as shown in Fig. (3).

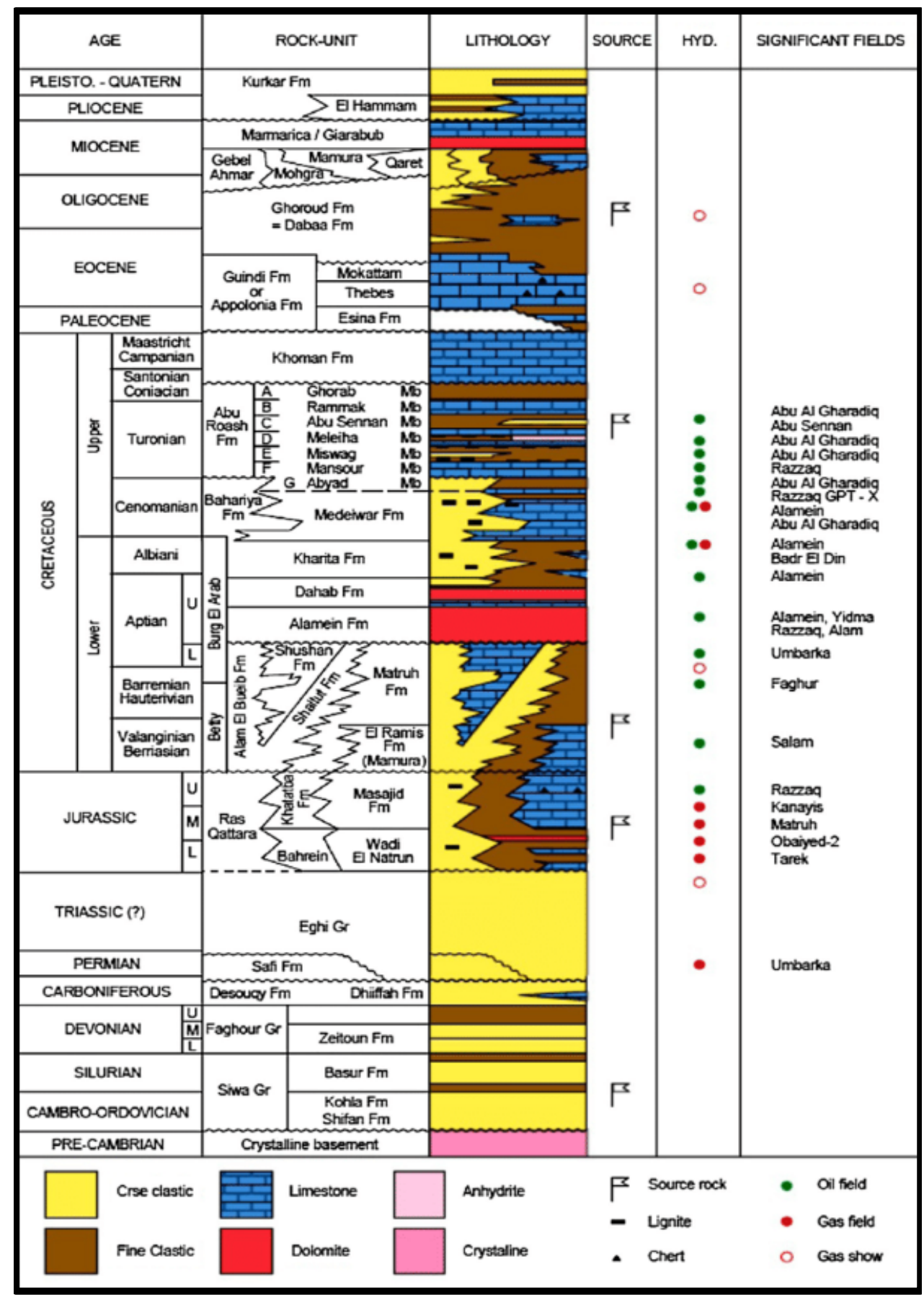

Fig. 3: Generalized stratigraphic column of the northern Western Desert, modified after Schlumberger (1984).

The North Western Desert was subjected to three fault tectonic trends. According to (Abu El-Ata, 1988) and (Moustafa et al., 1985) these trends are of Early to Late Tertiary ages. The first trend set the (ENE to E-W); they were reported to be of Late Cretaceous age. The second fault trends are having (NNW-SSE to NW-SE) directions and they are of Early Oligocene age (Meshref, 1988). The third trend 
3D seismic interpretation and structural analysis of Sitra-8 field

resulted in the NE-SW anticlines, which are related to the Syrian Arc System of Late Cretaceous-Early Tertiary age, Fig. (4).

Dolson, et al. (2001) concluded that Sitra Field contains a series of right stepping enechelon faults which produced WNW-ESE trending horst blocks, Fig. (5). Abu Gharadig basin has an irregular rhomb shape and includes at least three sub-basins of a similar shape and predominantly controlled by ENE- to E-W-oriented faults which parallel to their long axes (Mohamed et al., 2019).

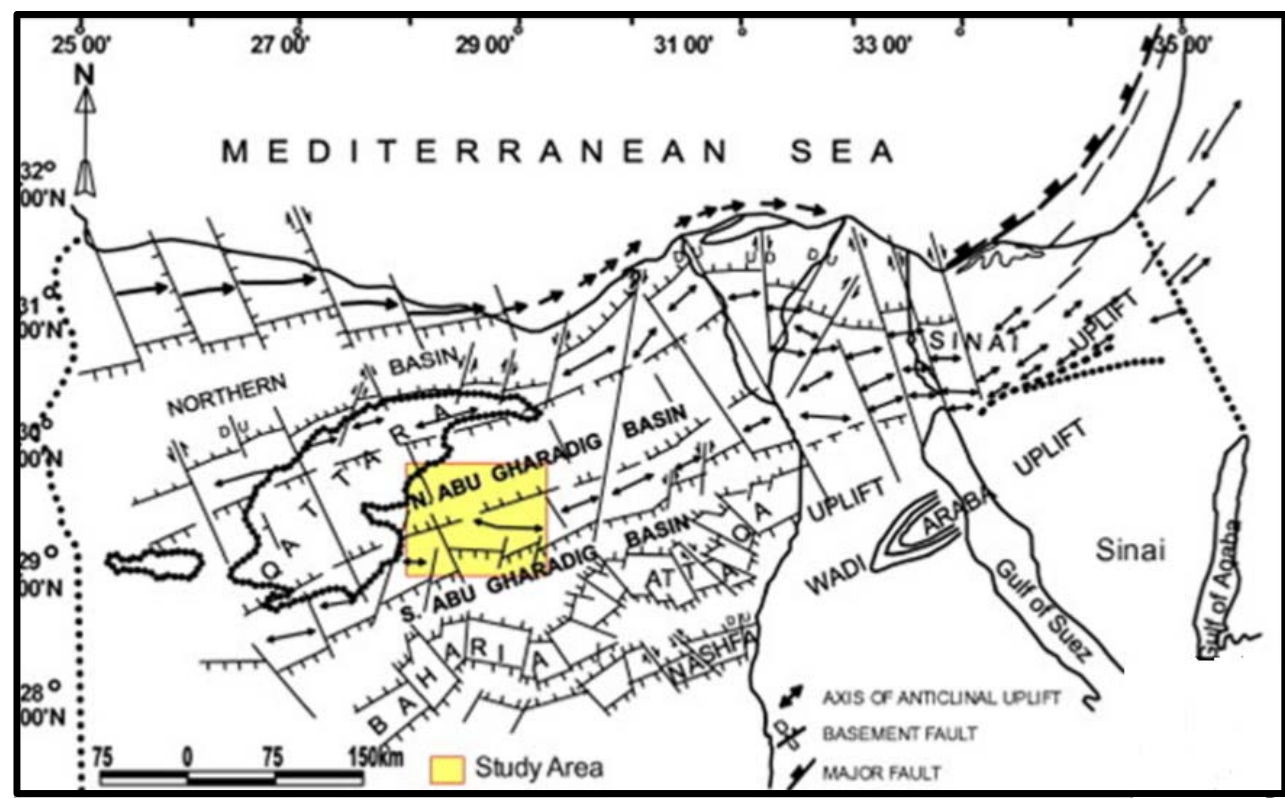

Fig. 4: Basement tectonic map of the Northern Western Desert, after (Meshref, 1988).

Fig. 5: Mesozoic and Cenozoic basins in the Western Desert and the main fault trends, modified after (Dolson et al., 2001).

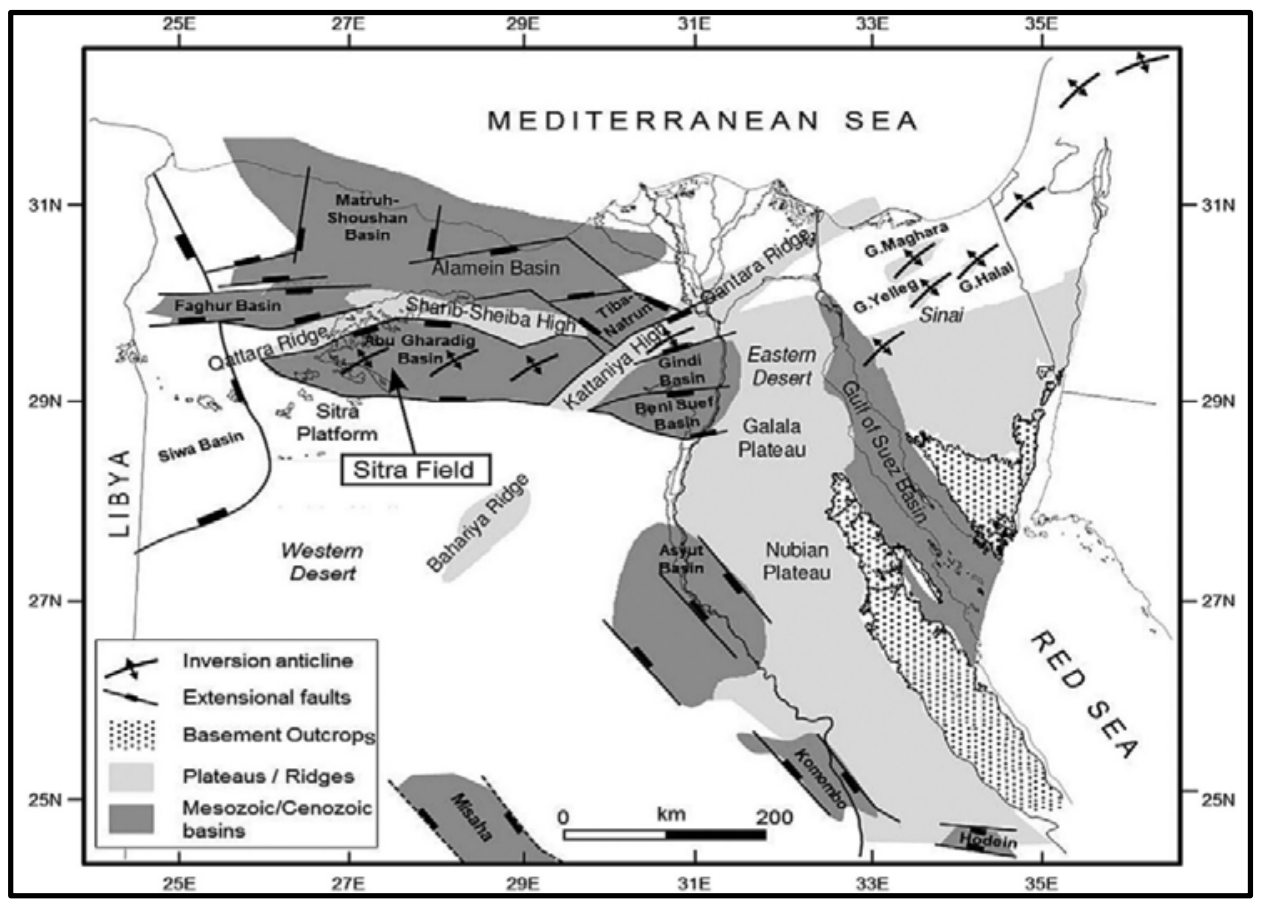

According to (Lotfy, 1989), the Initiation of the Abu Gharadig basin started during the Late Jurassic as a result of the intrusion of a deep-seated basaltic and dolerite mantle bulge, related to the early phase of the Alpine orogeny. The proposed model which postulated by (Meshref et al., 1988) displayed that the changed movement direction of the African Plate during the Late Cretaceous from the Eastward to the Westward might probably caused the rejuvenation of the ENE- to E-W-oriented faults. This in turn, produced the shear zones in the basin and then followed by the formation of rift basin, Fig. (6). 


\section{SEISMIC INTERPRETATION AND STRUCTURAL ANALYSIS}

The main target of achieving the structural interpretation of the seismic sections is searching for the structural traps, which bear hydrocarbons. The interpretation process is often carried out supporting the ordinary exploration activity procedures, which are associated with the available information coming from the subsurface geology (El-khadragy and Sharaf, 1994).

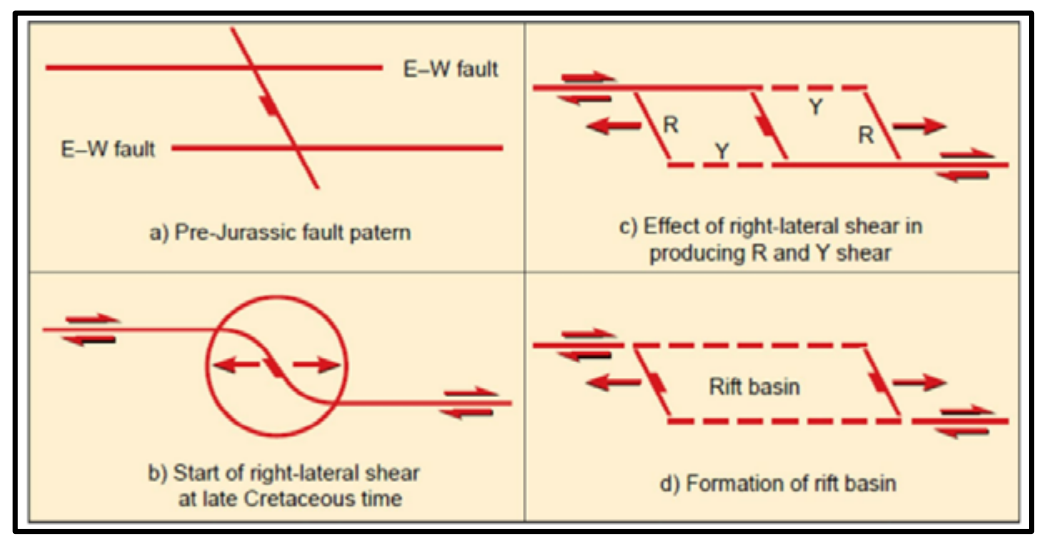

Fig. 6: Proposed model for Abu Gharadig basin, modified after Meshref et al. (1988).

In all cases of seismic interpretation, the seismic reflectors, which are related to certain lithologic units, are picked for the purpose of delineating the various geologic structures. These reflectors are also tracked laterally for any facies changes appear along the seismic sections for the evaluation and determination of the reservoir configuration and the related hydrocarbon volumes (Avseth et al., 2005).

To study and analyze the structural elements in the study area, the authors tracked some horizons above and below the Abu Roash-C Member (the objective horizon marker). Therefore, the top Abu Roash-A Member, top Abu Roash-E Member, and Alamein Formation have been picked, to define the existing structures, which influence the Abu Roash-C Member of the Upper Cretaceous reservoir. The 3D seismic volume including the five used wells namely: Sit-8-3, Sit-8-24, Sit-8-27, Sit-8-29 and Bed-3-1 are displayed in Fig. (7).

Fig. 7: The 3D seismic volume including the wells.

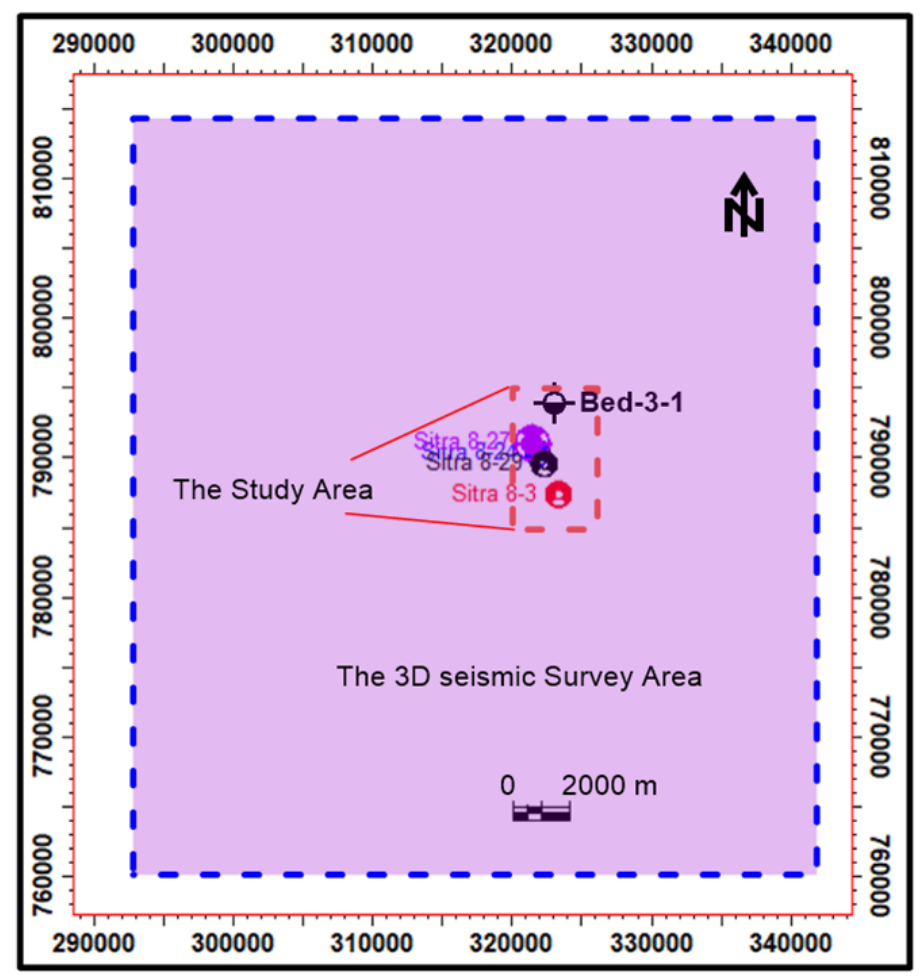


3D seismic interpretation and structural analysis of Sitra-8 field

In the present study the authors used 20 seismic lines to carry out the seismic interpretation in the study area. The locations and the numbers of these seismic sections are illustrated in Fig. (8). The CGG Company was contracted to conduct a 3D seismic survey for Shell Winning N. V. Company in the northern Western Desert of Egypt. The 3D seismic survey covered what is called BED and Sitra-08 area and it was composed of 15 swaths. It was completed on May, $21^{\text {st }}$, 2008, when the production process started (Shell, 2008). This in turn was reflecting a stage of development rather than an exploration one.

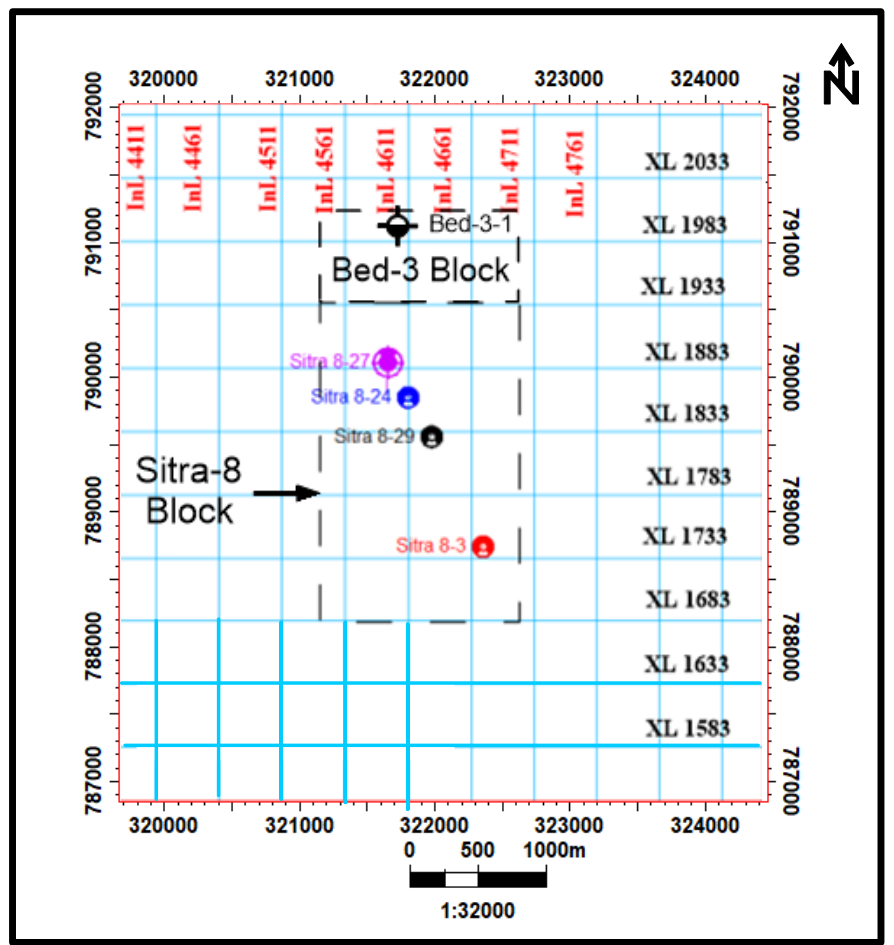

Fig. 8: The shot-point location map of 2D configuration extracted from the $3 \mathrm{D}$ volume.

The main goal of the structural interpretation of the seismic sections is the delineation of hydrocarbon traps. This task usually is carried out in parallel with the continuity of the exploration work and it needs a deep review for the subsurface information in the investigated area. The seismic reference datum for these seismic sections is the mean sea level.

The interpretation of seismic data is a process of transforming the physical responses displayed by the seismic lines into geologic information of interest, concerning either the stratigraphic succession or the structural style of the seismic data. The initial step for the interpretation into major geologic structures depends on the seismic reflectors. The process of tracing reflectors within a given seismic line and transferring the geological information from line to line at the tie points has to be applied carefully (Avseth et al., 2005).

The Abu Roash Formation is subdivided informally into seven members and they are arranged downwardly as: A, B, C, D, E, F and G. The type section of the Abu Roash Formation is the Mubarak-1 well, where the formation is composed mainly of calc-arenite with shale intercalations (E. G. P. C., 1992).

\section{Identification of the Seismic Boundaries}

Four seismic boundaries were detected distinctly and interpreted in the study area. The picked horizons are: Abu Roash-A, Abu Roash-C and Abu Roash-E Members (Upper Cretaceous), as well as the Alamein Formation (Lower Cretaceous). They are discussed in details as follows:

i) The Upper Cretaceous Boundaries.

The Upper Cretaceous boundaries are represented by three lithologic units namely: Abu Roash-A, Abu Roash-C and Abu Roash-E Members.

1. Abu Roash-A Member (A/R-A), Fig. (9). 


\section{El-Kharboutly, et al.}

2. A/R-A is of Coniacian age. It was present at $-1770 \mathrm{~m}$. sec. (TWT) in the southeastern corner of the area in Sitra-8-3 well, while it was picked at -1740 m. s. (TWT) in the northwestern part in Sitra-8-27 well. This variation of Abu Roash-C Member tops along the different wells can be interpreted as the direct effect of the normal faults which throw toward the North. The top of (A/R-A) reflector represents an acoustically hard to soft transition (soft kick) and it is displayed on the 3D view as (negative) blue loop.

3. Abu Roash-C Member (A/R-C), Fig. (10).

4. The A/R-C clastics are of Turonian age and are enclosed between two transgressive marine carbonate intervals (Abu Roash "B" and "D" Members). They are interpreted to be maximum flooding surfaces. Abu Roash-C was picked in the southeastern part of the area at -1973 m. s. (TWT) in Sit 8-3 well and in the northwestern corner at -1845 m. s. (TWT) in Sit 8-27 well. The top A/R-C reflector represents an acoustically hard to soft transition (soft kick) and it is displayed on the 3D view, as (negative) blue loop.

5. Abu Roash-E Member (A/R-E), Fig. (11).

6. A/R-E is of Turonian age and it is mainly composed of sands and shale. It is observed in the southeastern part of the study area at $-1990 \mathrm{~m}$. s. (TWT), while in the northwestern corner it is at -2110 (TWT) in Sit 8-27 well. The top of A/R-E reflector represents an acoustically soft to hard transition (hard kick) and it is displayed on the 3D view, as (positive) red loop.

Fig. 9: The Abu Roash-A Member Structural-time map.
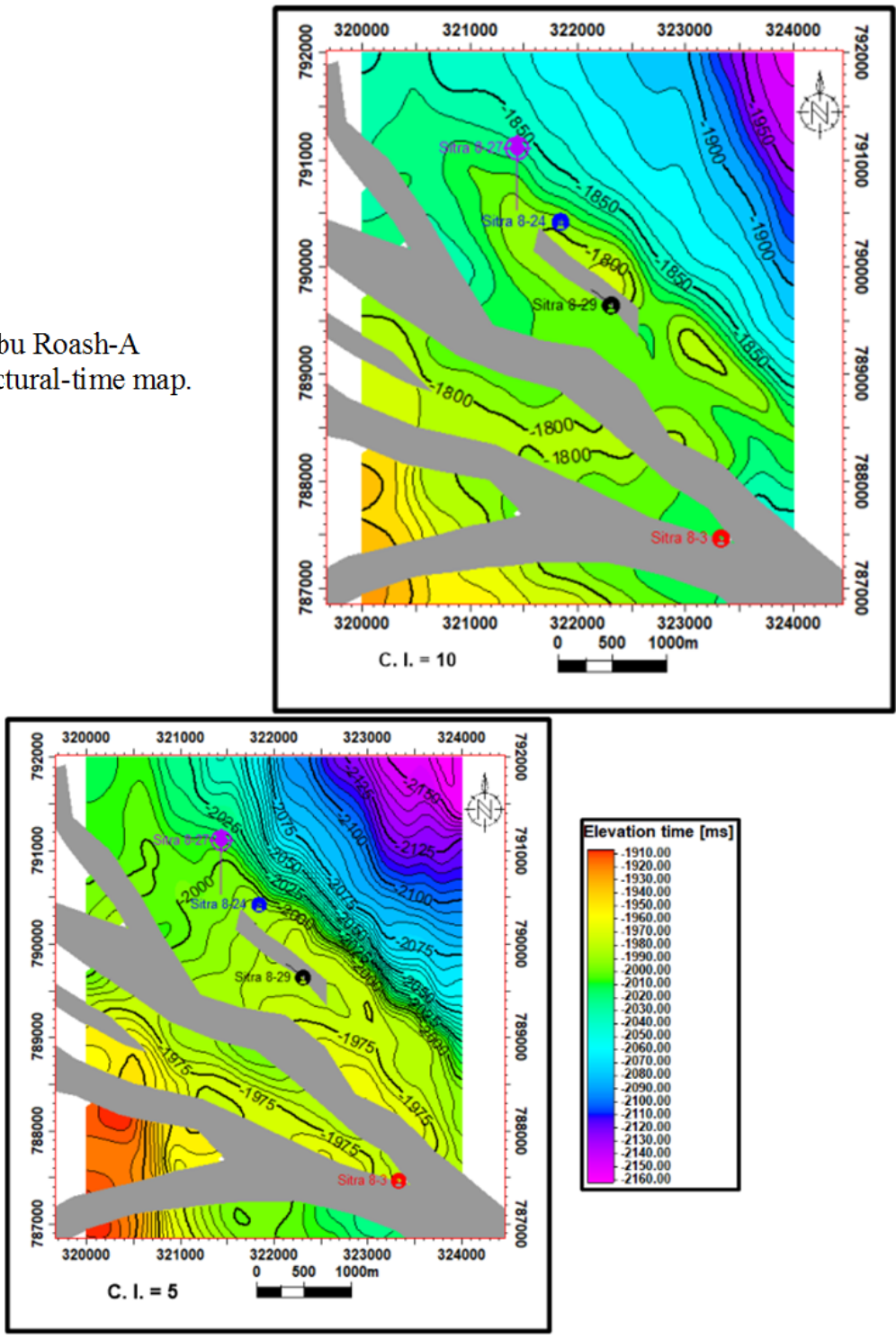

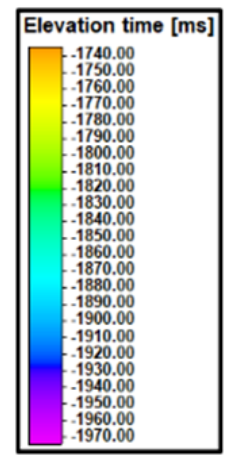

Fig. 10: Abu Roash-C Member Structuraltime map 
3D seismic interpretation and structural analysis of Sitra-8 field

Fig. 11: Abu Roash-E Member Structural-time map.

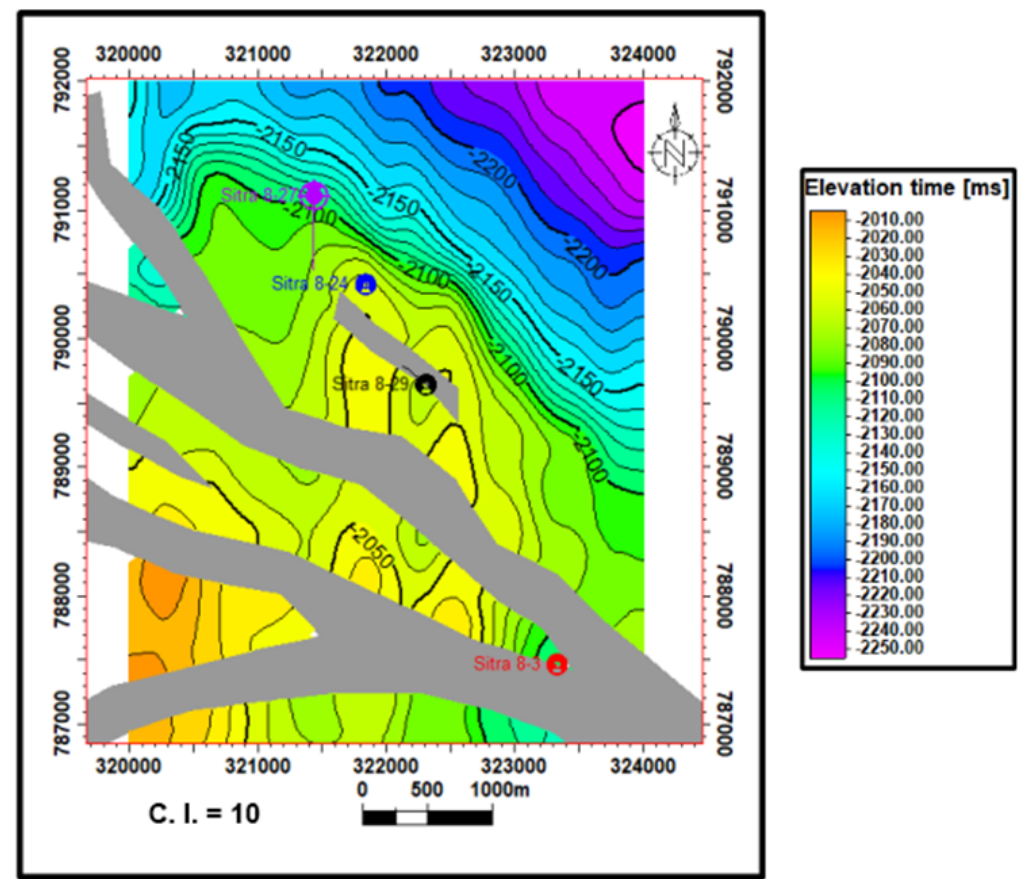

\section{The Lower Cretaceous Boundary}

The Lower Cretaceous boundary is represented by the Alamein Formation, Fig. (12). It is detected in the southeastern corner of the area at $-3600 \mathrm{~m}$. s. (TWT) in Sit 8-3 and it was detected at $-3825 \mathrm{~m}$. s. (TWT) in Sit 8-27 in the northwestern corner of the study area. The top of Alamein Formation reflector represents an acoustically soft to hard transition (hard kick) and it is displayed on the 3D, view as (positive) red loop.
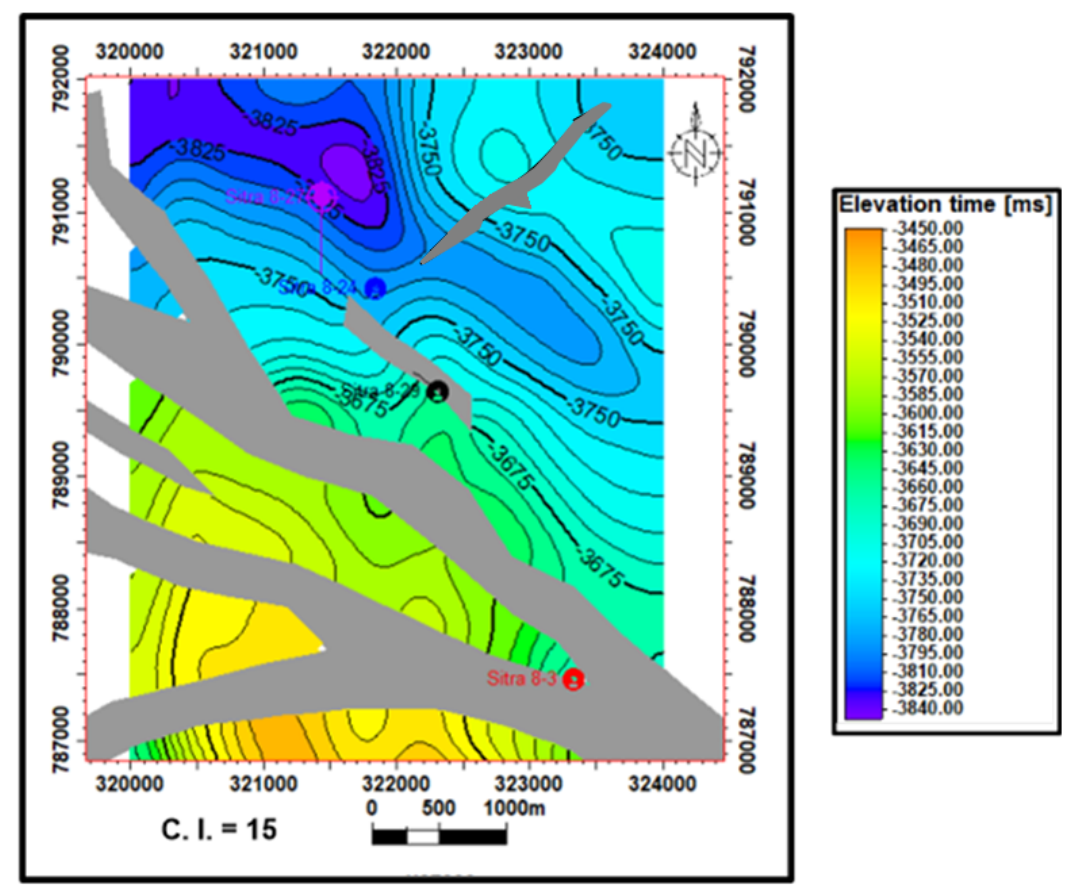

Fig. 12: Alamein

Formation Structuraltime map.

It is obvious that the study area displays a system of tectonic faults varies in influences as we move down from the Upper Cretaceous boundaries to the Lower Cretaceous ones, as shown in (Figs. 9, 10 and 11). The major set of faults is the N-W oriented faults; they are representing the major control of the Oligocene (Gulf of Aqaba) trends. The E-W and NE-SW normal faults of Cretaceous age are the second most frequent trend. 
In addition, there is an evidence of slight compressional forces near the center of the area of study area. This is marked by rejuvenation on one of the NW-SE normal faults reversing the direction of the movement of the hanging wall to be ended transferring the fault type to be reverse instead of its original normal form.

\section{The Major Structural Features Displayed by the Seismic Data.}

Abu Gharadig basin was formed in an early stage in the Paleozoic time and it was reactive continuing to develop as a result of the strong extensional tectonics which affected the northern Western Desert in the Mesozoic. Abu Gharadig basin was reformed at the Early Cretaceous on a right stepped en-echelon set of normal faults. Its opening was a right lateral slip movement of a diagonal fault cutting these normal faults (E.G.P.C., 1992).

By looking to the different seismic volumes in the investigated area and by reviewing the previous work done on our area or even nearby it, we can draw a clear continuous image about the main structures delineated from the 3D seismic data. The recognized structures are mainly: normal faults, strike slip faults, growth faults, fault blocks structures and reverse faults. The authors were cautious in their interpretation and they give a clear attention to the vertical exaggeration factor which can make the faults interpretation unreal.

Figures (12 and 13) are displaying some samples of the interpreted seismic sections respectively. The types of structures observed in the seismic lines, are listed in details, as follows:

\section{i) Normal faults.}

The area is characterized by an excess of normal faults, which frequently appear in the study area having two different sets. The first set is of NW-SE direction and affecting the Upper Cretaceous horizons and older boundaries. They were postulated to be of Miocene age (Said, 1990). The second set of normal faults is mainly of Late Cretaceous age and they are oriented NNE-SSW; they are abundant in our area. These two sets are both resulted from an extensional tectonics and can be seen clearly in the Cross-line seismic sections, Fig. (13).

\section{ii) Strike Slip Faults.}

The strike slip faults are the least in the study area and they are few in number; they are mainly right lateral strike faults. The strike slip faults could be detected from the seismic sections by detecting the shifting places of similar offsets. Strike slip faults can be determined also by analyzing the fault blocks where they can reflect a flower structure or by studying an abrupt change in the trace of the fault plane, as in Fig. (14).

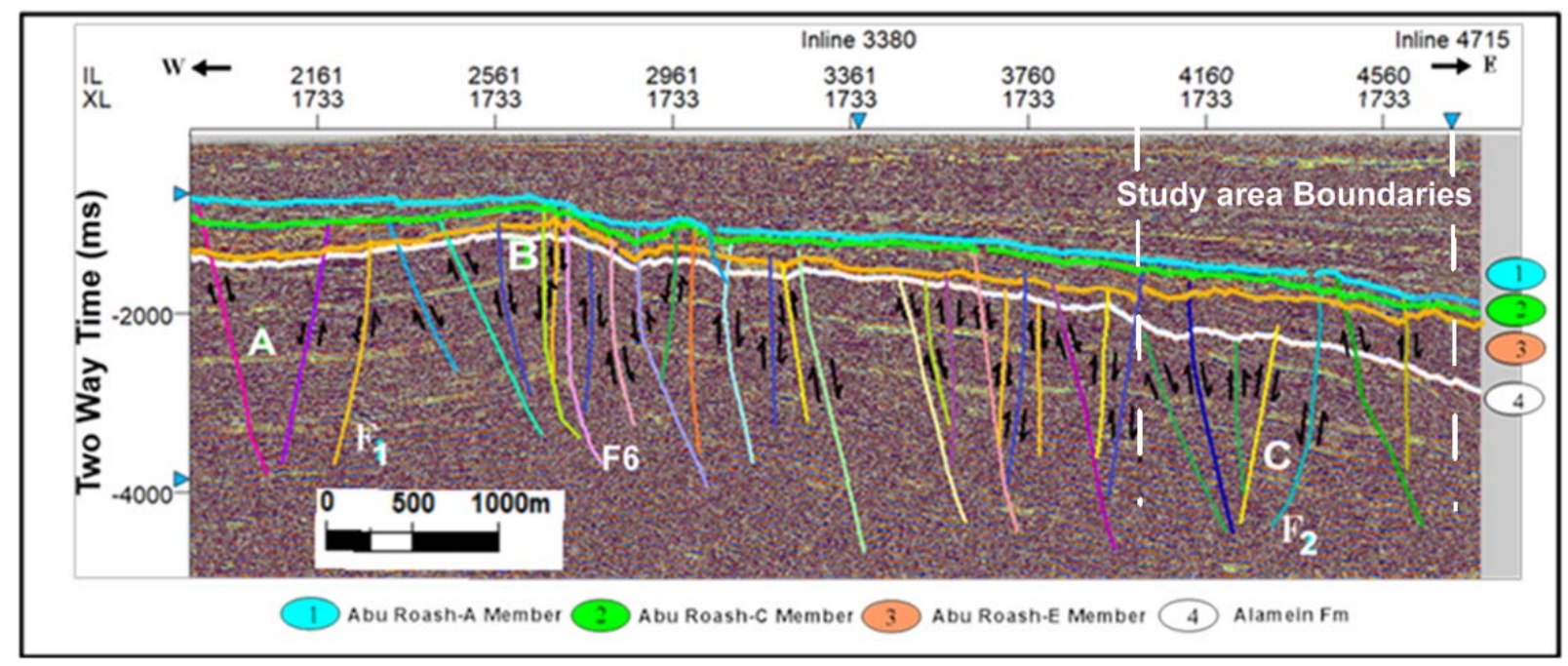

Fig. 13: The interpreted Cross-line seismic section No. 1733. 
3D seismic interpretation and structural analysis of Sitra-8 field

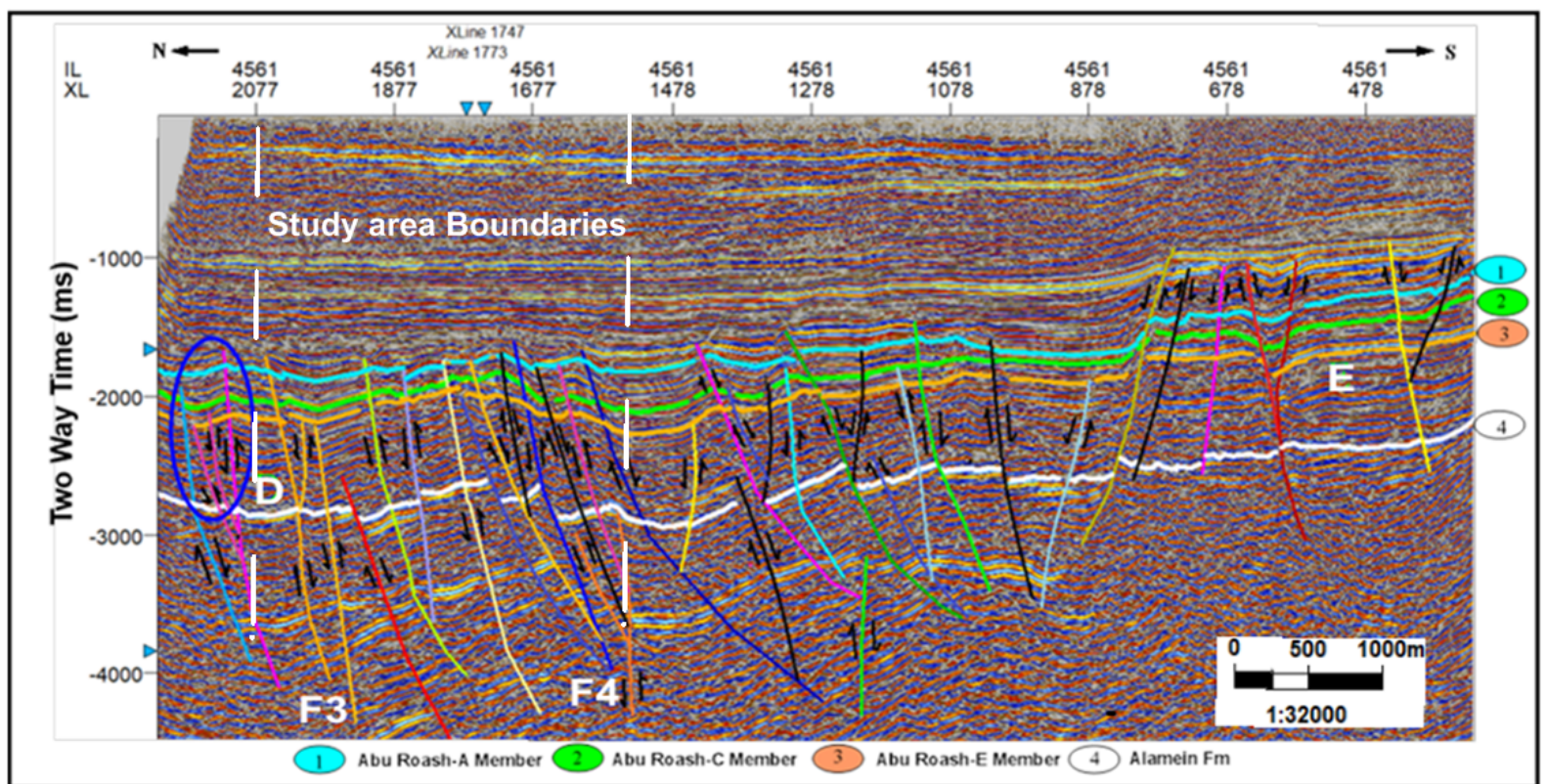

Fig. 14: The interpreted Inline seismic section No. 4561.

\section{iii) Fault Blocks.}

Fault blocks can be defined as massive blocks which are bounded by fault planes in threw in two opposite sides. Fault blocks also could be uplifted blocks or dropped blocks. The fault blocks could rotate when the fault planes on its boundaries are curved such as the case in listric faults. The depressed fault blocks are characterized by sediment accumulation. The Upper and Lower Cretaceous rocks are marked by that kind of structure. Fault blocks are clearly indicated in Fig. (13), the fault blocks (A, B and C) are depressed faulted blocks, while blocks (D and E) are a good examples of uplifted faulted blocks, Fig. (14).

\section{iv) Growth Faults.}

Growth faults are syn-depositional faults which concave up and bend toward the basin direction. The fault $\left(F_{6}\right)$, which is appeared in Fig. (13), was interpreted as a growth fault near to the south border of the study area. The power of the cross-sections is much more helper when we have a complicated structural pattern as in the current investigated area, Figs. (15 and 16).

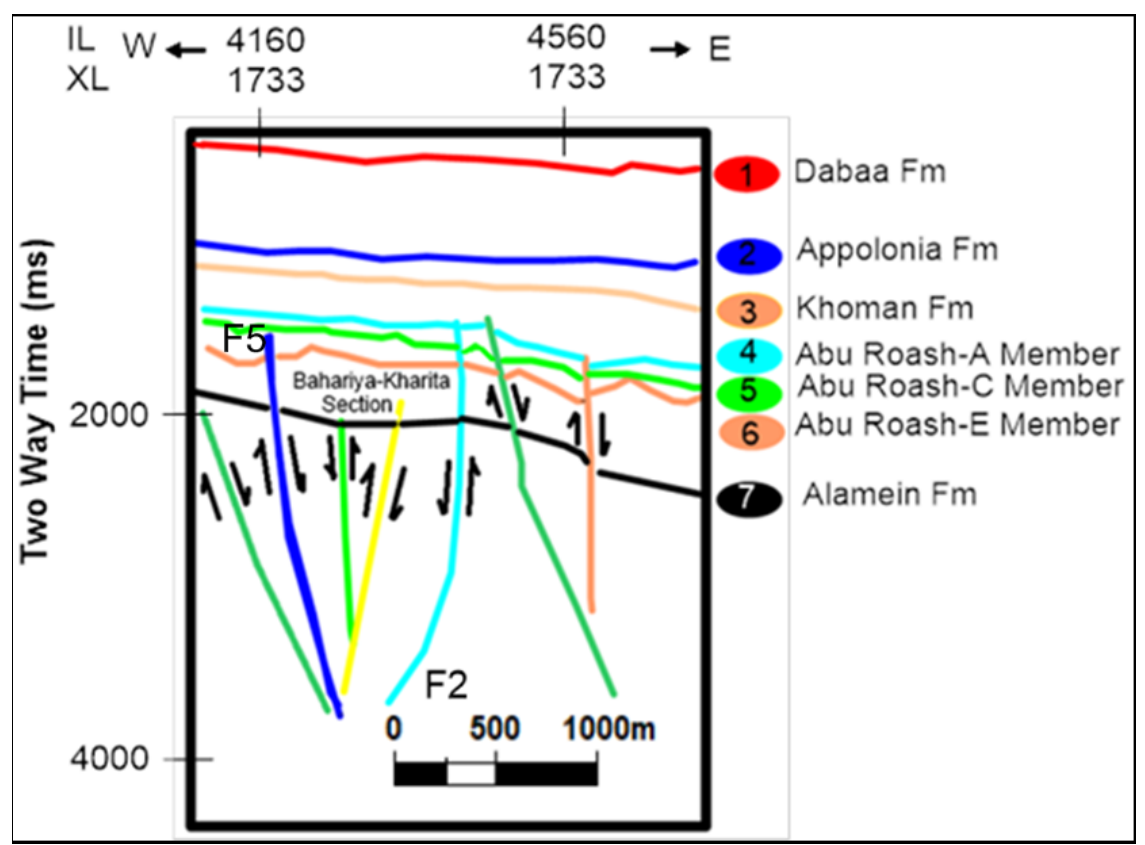

Fig. 15: Geological cross section through the Crossline No. 1733. 
El-Kharboutly, et al.

Fig. 16: Geological cross section through the In-line No. 4561.

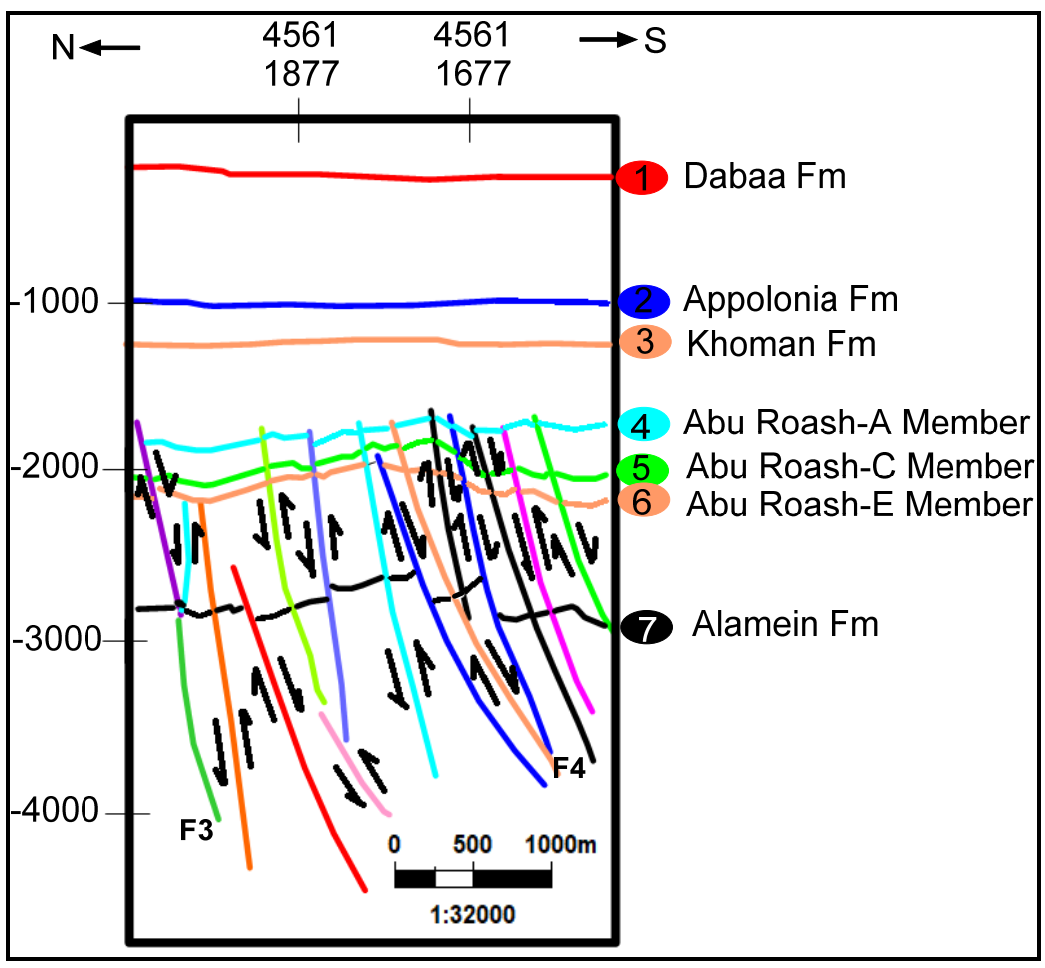

\section{v) Reverse Faults.}

The compressive stress, which accompanied the collision between European Plate and the African Plate has its influence in the area. Several numbers of reverse faults were spread northward, Fig. (14).

There is an obvious thickening of the Bahariya- Kharita section toward the eastern side as a result of the Jurassic - Eearly Cretaceous rifting along the NE-SW and E-W fault trends. The thickening of the Appolonia section eastward was related to the post Oligocene normal faults relaxation. The excess of antithetic faults toward the south, as in Fig. (14), can be related to the tectonic stress coming from the right-lateral slip components of Mediterran faults of E-W direction.

\section{Time-Depth Conversion.}

The time to depth conversion is an important procedure in seismic interpretation. The interpreter by time-depth conversion is transferring the structural information on the top of a targeted horizon, for the purpose of combining wells and converting the seismic time domain into depth domain, through the average velocity distribution. The calculation of the converted depth is occurred at locations, where both the wells and seismic data are tied together.

The wells are used as control and they have to go through the event of interest. The event depth $\mathbf{z}$ can be measured from the well control and the reflection time $\boldsymbol{t}$ (TWT) can be obtained from the seismic data at the same event. The depth conversion velocity is given by the following equation (Dix, 1955):

$$
\text { The velocity }(\mathrm{v})=2 \mathrm{z} / \mathrm{t}
$$

Then, the values of the velocity in different wells is posted to a map, it is called velocity map. The conversion process can be obtained by multiplying the time structure map and the depth conversion velocity map corresponding values, as follows:

$$
\mathrm{Z}(\mathrm{x}, \mathrm{y})=[\mathrm{v}(\mathrm{x}, \mathrm{y}) * \mathrm{t}(\mathrm{x}, \mathrm{y})] / 2
$$

Figure (17) displays the structural-depth map at the top of Abu Roash-C Member and the affecting structural faults. Abu Roash-C horizon is affected by a major set of NW- SE growth faults (CretaceousOligocene). The southeastern faults are considered synthetic faults and the northeastern ones are considered antithetic; both of them are reflecting extensional tectonics related to the opening of Abu 
3D seismic interpretation and structural analysis of Sitra-8 field

Gharadig basin. A right-lateral strike slip fault of WNW-ESE direction is passing along the southern part of the area cutting the normal faults. This strike slip fault is of Late Cretaceous and parallel to the Mediterranean fault trends. The Upper Cretaceous horizon illustrates a significant increase in depth toward the northeastern part of the study area.

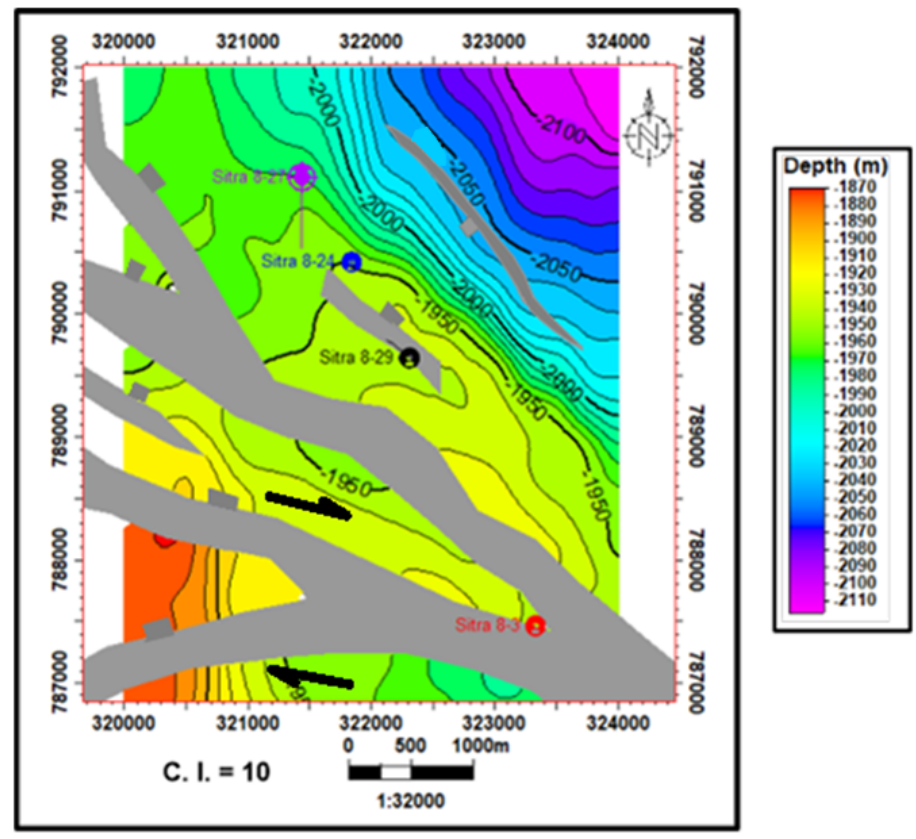

Fig. 17: The structural depth map on the top of Abu RoashC Member.

In case of Alamein Formation, which is of Lower Cretaceous age, the structural depth map indicates a relative increase in depth toward the northern part and the northwestern part of the study area, Fig. (18). The complexity of the subsurface structural pattern is implemented in the variation of depth. The EarlyJurassic rifting of might be responsible about the thickening of Alamein- Abu Rosh section in the northeastern part of the area.

In addition to the major NW-SE normal faults in the southeastern part, there is existing NE-SW reverse fault which could be resulted in as a result of a reverse movement on an existing normal fault.

Fig. 18: The structural depth map on the top of Alamein Formation.

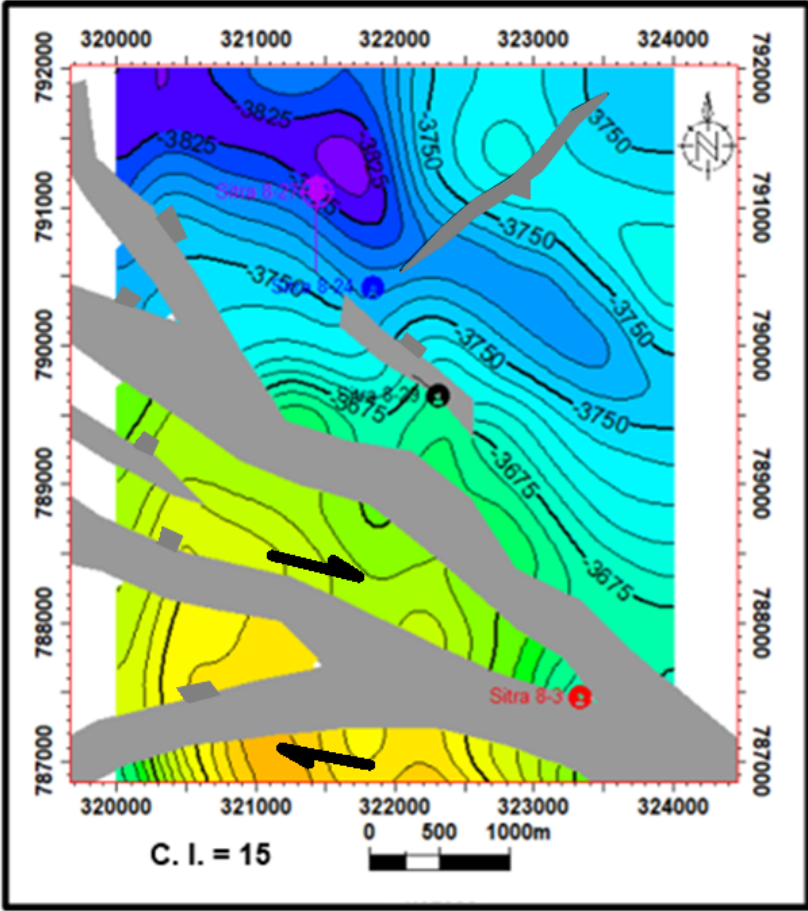

\begin{tabular}{|c|}
\hline Elevation time [ms] \\
\hline .3450 .00 \\
.3465 .00 \\
.3480 .00 \\
.3495 .00 \\
.3510 .00 \\
.3525 .00 \\
.3540 .00 \\
.3555 .00 \\
.3570 .00 \\
.3585 .00 \\
.3600 .00 \\
.3615 .00 \\
.3630 .00 \\
.3645 .00 \\
.3660 .00 \\
.3675 .00 \\
.3690 .00 \\
-3705.00 \\
.3720 .00 \\
.3735 .00 \\
.3750 .00 \\
.3765 .00 \\
.3780 .00 \\
3795.00 \\
.3810 .00 \\
.3825 .00 \\
.3840 .00 \\
\hline
\end{tabular}




\section{D Block Diagram}

The significance of the 3D structural modeling is very high particularly in the oil and gas sector. It can facilitate the communications between different departments for partitioning tasks and saving time and costs. In addition, it can draw a 3D simulation image through a small scale about the geometry of the subsurface boundary vertically and laterally (Hinsch et al., 2005).

Published surface and subsurface data about the Abu Gharadig basin was reviewed and integrated into the 3-D structural database, which obtained from the seismic interpretation. The vertical displaying of faults (represented by off-sets) was also uploaded to the structural model cube, using Petrel software. This is done to enable us to visualization and gathering the spatial distribution of the different data sets.

The faults were tracked with the horizon picking process and then the fault sticks entered the welldefined fault model grid. This enables us to observe the assumed flow. The surfaces can be made for the picked horizons, which are in the case Abu Roash-C Member (Upper Cretaceous) and Alamein Formation (Lower Cretaceous). The polygon of the faults also was estimated on the tops of the targeted horizons. The usage of the Petrel 3D window display is facilitating the process of making the 3D structural model.

Figure (19) illustrates the surfaces of Abu Roash-C Member and Alamein Formation. It is clearly that, there are numerous complex structures affecting the two horizons. Faults are dividing the horizon area into more than twenty parts. The faults moved the horizons up and down, so we can have sand-sand juxtaposition that is a bad one, because it could reflect a leak of the hydrocarbons. Therefore, sand is not a good seal; accordingly, this case is frequently seen in Sitra-8 area and is giving rise to negative results.

\section{RESERVOIR EVALUATION}

\section{Core data Analysis}

The evaluation of a reservoir is depending basically on the estimation of its permeability, porosity, fluid saturation and formation thickness. Three common tools can determine the four basic parameters: core analysis, well logging, and pressure test analysis (Tiab and Donaldson, 2015). In the development stage, core analyses allow the estimation of the hydrocarbon reserve and the determination of the contacts between reservoir fluids.

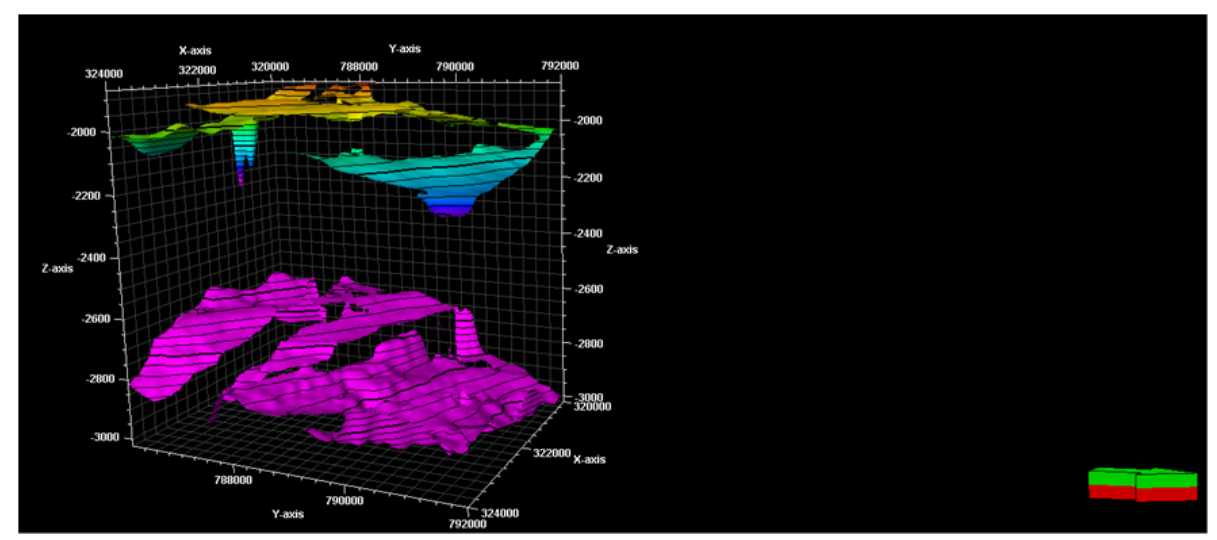

Fig. 19: An Oblique $3 \mathrm{D}$ view displays the two surfaces Abu Roash-C and Alamein Formation.

One of the most important parameters in petroleum industry is the detection of the productive reservoirs in the investigated area. When the reservoir zone is defined, it is necessary that, the targeted reservoir has to be subjected to an evaluation process. This process incudes the classification of reservoir intervals on the basis of qualifications, i.e. the differentiation between the intervals which can serve as a good reservoir for oil and which are less.

The electric well-logs measurements are the major task for any well, after the completion of the drilling (Salem, et al., 2015). We can define the reservoir rocks through the whole drilled succession. In addition, the logging tools also address the physical properties of rocks and their parameters in the invaded zone, such as: the lithologic units, porosity, water saturation percentage, permeability and pore configuration geometry. 
3D seismic interpretation and structural analysis of Sitra-8 field

The available core data in Sitra area were coming from Sitra 8-1B and Sitra 8-17 wells, as shown in table (2). The extracted litho-stratigraphic properties of the sedimentary layers were written in charts with scale 1:40, including the variations in facies changes vertically and then were plotted against the GammaRay (GR) log in one column with subdivisions for determining the depositional environment.

Table 2: The core data description of Sitra 8-1B and Sitra 8-17 wells, after BAPETCO (2010)

\begin{tabular}{|c|c|c|c|c|c|c|c|}
\hline \multirow{2}{*}{ Well name } & \multirow{2}{*}{$\begin{array}{c}\text { Core } \\
\text { No. }\end{array}$} & \multicolumn{2}{|c|}{$\begin{array}{c}\text { Cored interval without shift } \\
\end{array}$} & \multirow{2}{*}{$\begin{array}{c}\text { Lop } \\
\text { (mbdf) }\end{array}$} & $\begin{array}{c}\text { Bottom } \\
\text { (mbdf) }\end{array}$ & \multirow{2}{*}{$\begin{array}{c}\text { Length per } \\
\text { core (ft) }\end{array}$} & \multicolumn{2}{|c|}{$\begin{array}{c}\text { Top } \\
\text { (mbdf) }\end{array}$} & $\begin{array}{c}\text { Bottom } \\
\text { (mbdf) }\end{array}$ & Formation \\
\hline Sitra 8-1B & $\# 1$ & 2940.50 & 2959.00 & 18.50 & 2947.00 & 2965.50 & Abu R. C \\
Sitra 8-1B & $\# 2$ & 2959.00 & 2977.00 & 18.00 & 2965.80 & 2983.80 & \\
Sitra 8-17 & $\# 1$ & 2837.17 & 2864.23 & 27.06 & 2837.40 & 2864.46 & Abu R. C \\
\hline
\end{tabular}

\section{Porosity and Permeability Calculations.}

The porosity is defined as the ratio of the volume of pore spaces in a certain rock to the total volume of that rock (Cannon, 2016). The porosity can be determined from density log by using the following equation:

$$
\emptyset=\frac{\rho_{m-} \rho_{b}}{\rho_{m-} \rho_{f}}
$$

where:

$$
\begin{aligned}
& \emptyset=\text { The porosity } \\
& \rho_{b}=\text { Bulk density (density log reading) } \\
& \rho_{m}=\text { Matrix grain density and } \rho_{f}=\text { Aapparent fluid density }
\end{aligned}
$$

Practically, some logs can measure porosity, although there is no specific logging tool can do this directly. The non-conventional Triple Combo Technique is used in the current study by calibrating the Gamma-Ray log results (lithology log) with both the Rock Bulk Density log (pore measurements) and the Resistivity log (fluid measurements). The Petrel software helps in the estimation and presentation of the calculated porosity.

Neutron log was used to determine the hydrogen concentration in the formation through the estimation of the Hydrogen Index (HI). The different well log responses for Sit 8-29 well is displayed in Fig. (20). In shale-free rocks where the pore space is filled with water or oil, the neutron log directly measures the liquid porosity. When the pores are filled with gas the concentration of hydrogen is reduced, resulting in a lower porosity reading from the tool, the so-called gas effect; there is a 'cross-over' with the density log when the neutron porosity is less than the bulk density in the porous and permeable zones.

Water saturation $\left(S_{w}\right)$ is a term, which is applied for the measure of pore volume filled with water; it can be calculated according to Archie's Equation as follows:

where,

$$
\mathrm{S}_{\mathrm{w}}=\sqrt[n]{\frac{a R_{w}}{\emptyset^{m} R_{t}}}
$$

$\mathrm{S}_{\mathrm{w}}=$ Water saturation fraction, $\mathrm{R}_{\mathrm{w}}=$ Resistivity of formation water, $\mathrm{R}_{\mathrm{t}}=$ Resistivity of invaded formation, $\varnothing=$ Porosity fraction, $\mathrm{m}=$ Cementation exponent, $\mathrm{n}=$ Saturation exponent, and $\mathrm{a}=$ Empirical constant. Equation (4) is applied when the framework is not electrically conductive (clean sand) but in reality, shale usually exists with sand and in this case the water saturation $\left(\mathrm{S}_{\mathrm{w}}\right)$ can be calculated by the following equation (Cannon, 2016):

$$
\frac{1}{R_{t}}=\frac{S_{w}^{2}}{F R_{w}}+X
$$

where,

$\mathrm{F}=$ Formation resistivity factor

$\mathrm{X}=$ Conductivity of the shale component. 


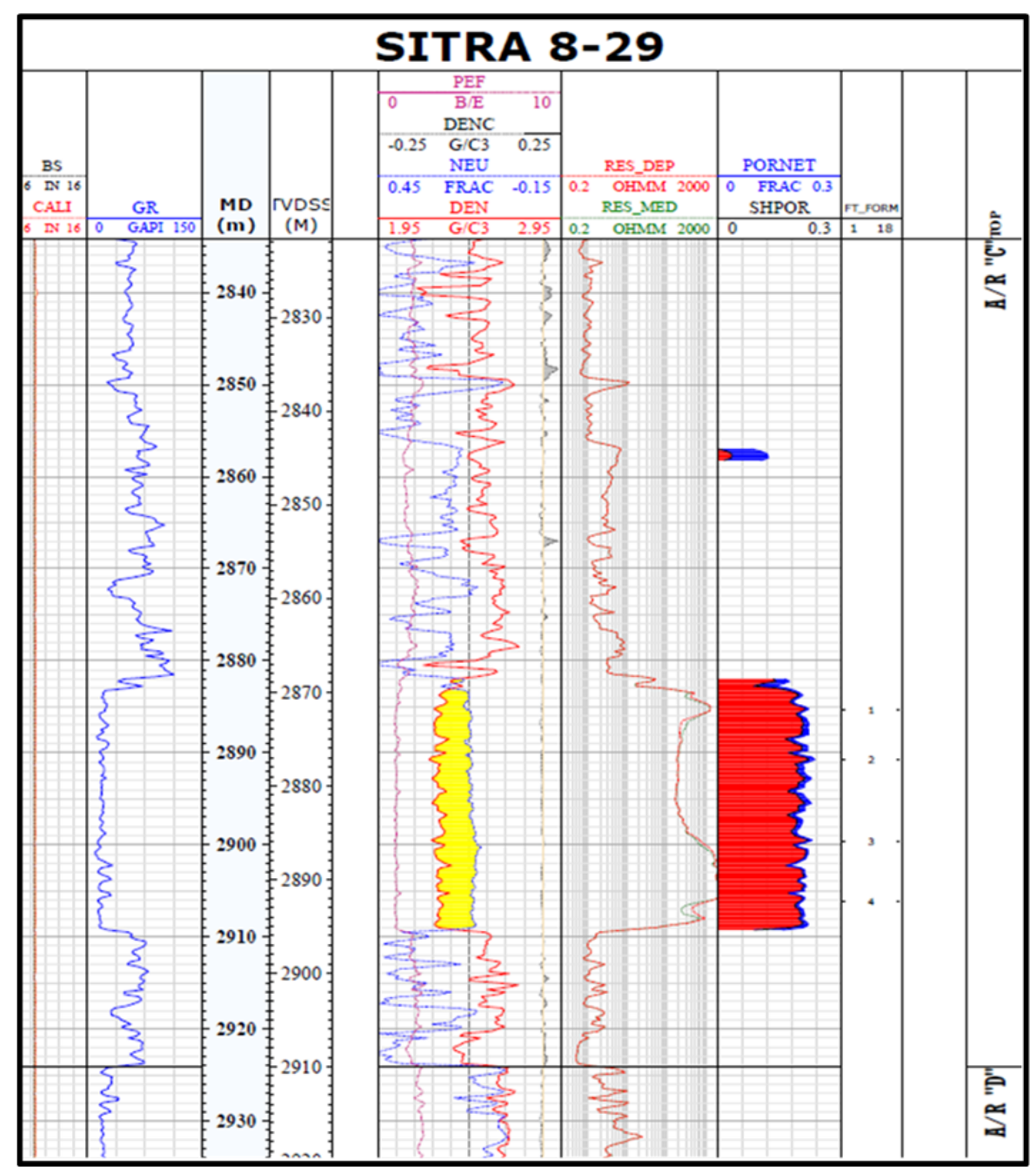

Fig. 20: ODT plot of Abu Roash-C upper sand on Sitra 8-29 well.

Irreducible water saturation ( $\mathbf{S}_{\text {wi }}$ ) is defined as the proportion of capillary-bound water that is immoveable by normal production processes. The irreducible water saturation varies with rock quality and will be higher in low-permeability rocks. The irreducible water saturation varies with rock quality and will be higher in low-permeability rocks. The irreducible water saturation $\left(\mathbf{S}_{\text {wi }}\right)$ can be obtained according to (Darling, 2005) from Equation (6):

where,

$$
\mathrm{S}_{\mathrm{w}}=\mathrm{S}_{\mathrm{wi}}+\mathrm{a}\left(\mathrm{J}^{\mathrm{b}}\right)
$$

$$
J=P_{c}[\sqrt{K / \varnothing}] / \sigma(\operatorname{Cos}(\theta))
$$

$\mathrm{P}_{\mathrm{C}}=$ capillary pressure in psi

$\mathrm{S}_{\mathrm{wi}}=$ irreducible water saturation

$\mathrm{K}=$ permeability

$\emptyset=$ porosity

$\sigma=$ interfacial tension between hydrocarbon and water

$\theta=$ contact angle between hydrocarbon and water

$h=$ height above free water level

$a$ and $b=$ constants to be fitted to the data

Permeability is the ability of rocks to allow petroleum fluids to flow through interconnected pores. Core permeability can be given from the following equation:

$$
K=10^{(a+b+\varnothing)}
$$


3D seismic interpretation and structural analysis of Sitra-8 field

The irreducible water saturation $\left(\mathrm{S}_{\mathrm{wi}}\right)$ versus porosity $(\varnothing)$ plots can help in recognizing the quality of rocks suitable for reservoir environment. Furthermore, the $S_{\text {wi }}-\emptyset$ plots can be considered a good indication for rocks containing mobile water. Figures (21 and 22) are illustrating the plots between $\left(S_{w i}\right)$ and $(\varnothing)$ for both Sit 8-3 and Sit 8-27 wells. The approximated linear relationship between the water saturation and the porosity in both wells give us a key factor about the low permeability and the high permeability subzones within the productive reservoir.

Furthermore, we can classify rocks above the straight line representing the plot equation as lower quality (low permeability) and the one underneath the straight line is of higher quality rocks (high permeability). When there are no significant lithologic variations as the case of the Abu Roash-C reservoir (we have either sand or shaley sand), the $S_{\mathrm{wi}}-\emptyset$ cross plots will indicate facies changes.

There exists a long history of permeability and porosity models (Saar, 1998). The permeability and porosity plots enable us to understand the relation between the microstructures of a specific rock and its permeability. In addition, the various facies in the realization of a certain model can be separated or recognized by these plots.

When a single empirical relationship holds for groups of facies, then these can be combined if there is no inherent geological difference between them. As for example, sheet sands should not be combined with channel sands even if there properties are apparently the same because they will have different depositional characteristics that may control flow in the reservoir.

Fig. 21. Porosity vs. Irreducible water saturation plot for Sitra 8-3 well
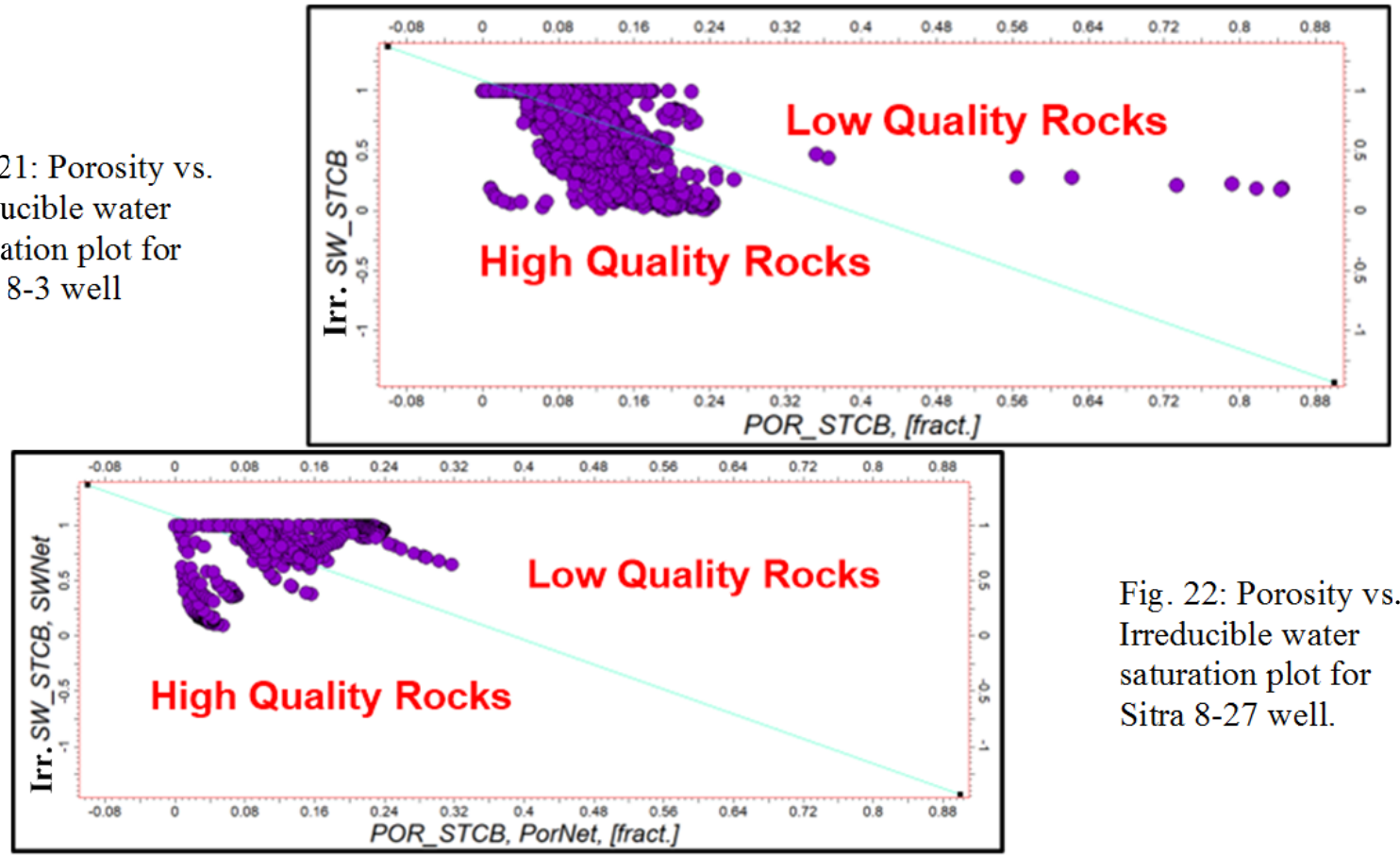

The porosity-permeability cross-plot is more effective in lithofacies determination. Figure (23) displays the cross-plot between porosity and permeability along Sit 8-27 well. We can differentiate between two facies having the same porosity range: the first one of higher permeability values $(>10 \mathrm{mD})$ and the second one of lower permeability values $(<10 \mathrm{mD})$. The authors interpreted the depositional environment of the two facies as tidal channel bar and tidal flat environments. When it comes to productivity, Sit 8-27 well includes a good quality Abu Roash-C reservoir but it is considered a tight reservoir ( $<50 \mathrm{mD})$. In addition, the sand-sand juxtaposition is causing a hydrocarbon leaking, which ended to classify the Sit 827 as water bearing well.

The integration between the core data result, the petrophysical data analysis and the wire logs interpretation, as well as the designed subsurface geological studies in the study area, put us in two possible scenarios, when it comes to the depositional modeling. 
Fig. 23: Permeability vs. Porosity plot for Sitra 8-29 well.

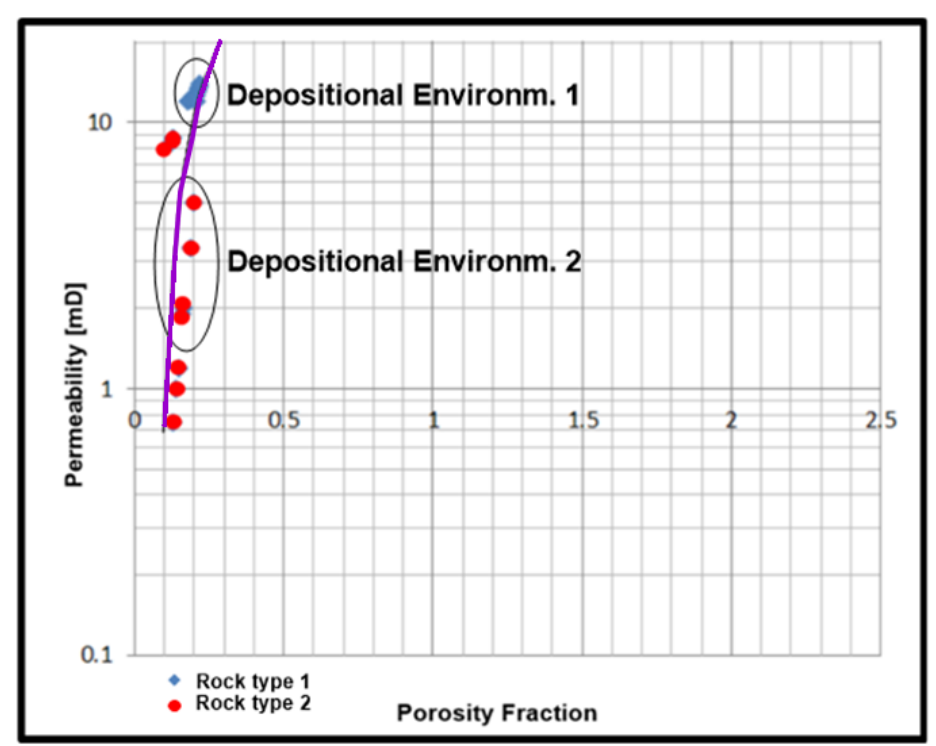

The first scenario can be established by dividing the reservoir sand zone into three facies degrading from the best quality to the less one. The three facies are respectively: Clean tidal channel (consisted of blocky sands), tidal channel (composed of sands and shaly sands), flat sand (made up of shaly sands). The second scenario, the sand zone reservoirs were subdivided into two facies: Tidal channel (sands and shaly sands) and tidal flat sands (shaly sands).

The authors in the current study chose the second Scenario and they tracked Abu Roash-C Member reservoir based on the petroleum system of the study wells seeking for an explanation to the water bearing well problem such as the case of Sit 8-27 well, which have got the attention of too many researchers in the oil field. The authors through the reservoir evaluation qualitative and quantitative analyses made an attempt configuration of this problem through the lithofacies plots.

The complicated structural setting in Sitra 8 area makes it difficult for addressing the oil-leaking migration in certain reservoirs such as: Abu Roash-G. The possible solution of this problem for future appraisal is the application of the uncertainty lithofacies subsurface studies and the establishment of suitable conceptual models for the productive reservoirs in the area.

The study introduced also new promising areas of hydrocarbons for the exploration or development purposes such as the proposed Sitra C-10-A well toward the northeastern part of the investigated area, as illustrated in Fig. (24). Where the extension of the single Abu Roash-C reservoir is broken into two intervals resulted in two fault blocks by the normal fault. Oil will be connected in the Oil Water Contact (OWC) model, while water will spill down to the bottom.

\section{CONCLUSIONS}

In Sitra 8 Field area, the most significant reservoir rocks are in the Upper Cretaceous strata and the major discoveries are in Abu Roash Formation. There are many structural traps in the study area, which are controlled by the existing faults in the study area. Some of these traps are potentially containing hydrocarbons but this is not reflected on the major productivity of the region by drilling. Several wells were reported water bearing and others were coming dry. In addition, the drilling process did not cover the whole area and it was left for development to be fully understood.

Unfortunately, seismic structures and well logging petrophysical analyses are isolated islands, without geologic interactions! Therefore, the present study proposes integration between these geophysical techniques and the designed subsurface geological studies in Sitra-8 Field area in the northern Western Desert of Egypt. This can be more helpful in any upcoming appraisal process in the future, which in turn will be reflected on the field development economically. 
3D seismic interpretation and structural analysis of Sitra-8 field

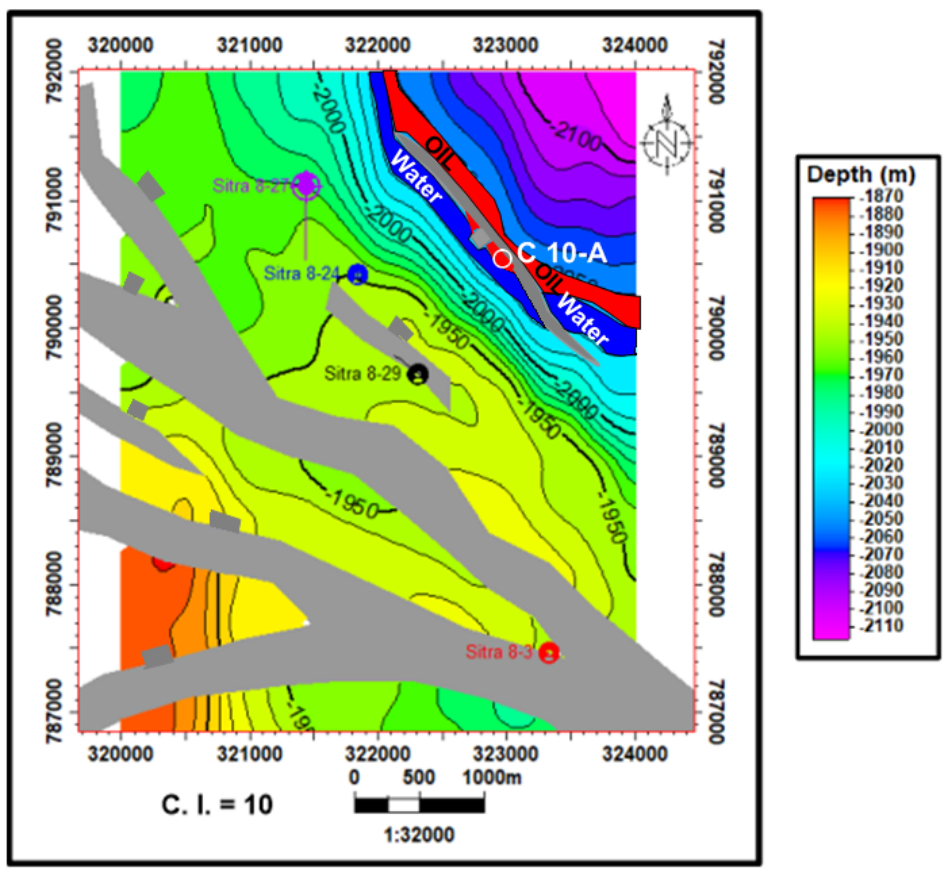

Fig. 24: The top of Abu Roash-C structural depth map showing the proposed future exploration well Sitra-C10-A according to the current study

The authors carried out 3D seismic interpretation in the study area for delineating the major structure elements of four horizons namely from top to bottom: Abu Roash-A Member, Abu Roash-C Member, Abu Roash-E Member and Alamein Formation. The first three horizons are of Upper Cretaceous age, while the Alamein Formation is of Lower Cretaceous age. The time maps of the four boundaries were constructed and the structural depth maps were produced. Several seismic Inline and Cross-line sections were interpreted covering the area.

The study area is characterized by an excess of normal faults, which frequently appear in having two different sets. The first set of faults is of Miocene age and they are directed NW-SE direction and affecting the Upper Cretaceous horizons and older boundaries. The second set is oriented NNE-SSW and they are Late Cretaceous in age. These normal faults were bounded by some growth faults revealing the presence of the extensional tectonics in the area.

In addition, there are a few right-lateral strike slip faults. They were detected by the existence of the flower structures and through tracing the complex geometry of the interpreted fault planes. The direction of the strike slip faults is E-W and is parallel to the Mediterranean trend. The 3D structural block-diagram in the area is displaying the vertical faults roots and the targeted horizons of Abu Roash-C Member and Alamein Formation. This enabled the authors to visualize the spatial of the combined datasets.

The petrophysical analyses, seeking the reservoir rock properties, were done by using the electric logs of four wells in the study area namely: Sit 8-3, Sit 8-24, Sit 8-27, Sit 8-29 wells and Bed 3-1 well from outside the study area. Salem et al., 2015 postulated that, the problem of Abu Roash-G reservoir in Sitra 8 area is the bad juxtaposition of Abu Roash-G in the foot walls of the tectonic faults, with the Abu Roash-C (sand-sand juxtaposition). This enables the liquid hydrocarbon to migrate through faults. He also gave an analogy for that situation in the near area of BED-3 Field.

Thus, potential for large oil accumulations in Abu Roash-G reservoir in the area is limited. As a result of the lacking of control on the minimum age of hydrocarbon generation, the relative timing of hydrocarbon generation and movement through fault planes is ambiguous.

The authors tracked the Abu Roash-C Member reservoir for the same problem and tried to introduce a suitable solution for the hydrocarbon leaking problem for the upcoming future appraisal. The study was a worthy challenge to find new promising areas, when it comes to the hydrocarbon exploration or development. The authors are recommending future drilling for development in the area of Sitra C-10-A in the northeastern part of the current area. 


\section{ACKNOWLEDGEMENTS}

The authors are indebted to both BAPETCO Oil Company and the Egyptian General Petroleum Corporation (E.G.P.C.) for providing the raw seismic reflection data of the study area which were used in the present 3D seismic study. The authors appreciate the staff of Bader El-Din Co. for their fruitful help. In addition, the authors like to express their deepest gratitude for the Department of Geophysics, Faculty of Science, Ain Shams University.

\section{REFERENCES}

Abu El-Ata, A. S. A. (1988): The relation between the local tectonics of Egypt and the plate tectonics of the surrounding regions using geophysical and geological data. In: E. G.S. Proc. $6^{\text {th }}$ Ann. Meet., Cairo, 92-112.

Abu El-Ata, A. S. A. (1990): The role of seismic-tectonics in establishing the structural foundation and saturation conditions of El-Ginidi basin, western Desert, Egypt. Egyptian Geophysical Society (EGS), the 8th Ann. Meeting, 150-189.

Abu-Hashish, F. M. and Said, A. (2016): Volumetric assessment through 3D geostatic model for Abu Roash "G" reservoir in Amana Field, East Abu Gharadig Basin, Western Desert-Egypt. J. Geol. and Geophys., 5(2), 12 P.

Avseth, P., Mukerji, T. and Mavko, G. (2005): Quantitative seismic interpretation. Cambridge Univ. Press, UK, 376 P.

BAPETCO (2010): Sitra 1, 2, 3, 5 \& 8 field development plan., Badr Petroleum Company, Cairo Pub., $260 \mathrm{P}$.

Cannon, S. (2016): Petrophysics: A practical guide. Wiley Blackwell, West Sussex, UK, 217 P.

Darling, T. (2005): Well logging and formation evaluation. Elsevier Inc., Burlington, MA, USA, 335 P.

Dix, C. H. (1955): Seismic velocities from surface measurements. Geophys., 20, 68-86.

Dolson, J. C., Shann, M. V., Matbouly, S. I., Hammouda, H. and Rashed, R. M. (2001): Egypt in the twenty-first century: petroleum potential in offshore trends. GeoArabia, (6), (211-230).

E.G.P.C. (1992): Western Desert oil and gas fields: A comprehensive overview. The 11th Petroleum Exploration and Production Conference, Egyptian General Petroleum Corporation, Cairo, 431P.

El-Saadany, M. (2008): Structural style and tectonic evolution of the central part of the northern Western Desert, Egypt. Ph. D. thesis, Fac. Sci. Ain Shams Univ., 267 P.

Lotfy, A. (1989): Modes of structural evolution of Abu Gharadig Basin, Western desert of Egypt as deduced from seismic data. J. Afr. Earth Sci. Middle East, 9, 273-287.

Meshref, W. M., Beleity, A. E. H., Hammouda, H. and Kamel, M. (1988): Tectonic evolution of Abu Gharadig basin. In: AAPG Bull.; United States, 72, No. CONF-8809346.

Mahmoud, H., Lotfy, H and Bakr, A. (2019): Structural evolution of JG and JD fields, Abu Gharadig basin, Western Desert, Egypt, and its impact on hydrocarbon exploration. J. Petroleum Explor and Production Techn., 9, 2555-2571.

Moustafa, A., Yehia, A. and Abdel-Tawab, S. (1985): Structural setting of the area east of Cairo, Maadi, and Helwan. Sci. Res. Ser., 5, 40-64.

Said, R. (1990): The Geology of Egypt, Balkema, A.A., Rotterdam, Netherland, 743P.

Schlumberger (1984) In: Well Evaluation Conference, Schlumberger, Cairo, pp. (1-64).

Saar, M. O. (1998): The relationship between permeability, porosity and microstructure in vesicular basalts. M. Sc., Univ. Oregon, USA, $101 \mathrm{P}$.

Salama, H., Darwish, M., Wahdan, M. and El-Batal, M. (2017): Identify re-development concepts to enhance Abu Roash "C" reservoir productivity Sitra area, Abu Gharadig basin, Western Desert, Egypt. Egypt. J. Petroleum, 26, 235-267.

Salem, I., Ghazala, H. and El Diasty, W. (2015): Prospect evaluation of BED-3 and Sitra oilfields, Abu Gharadig Basin, North Western Desert, Egypt. NRIAG J. Astronomy and Geophys., 4, (222-235).

Shell (2008): Final report: Bed-2 and W. Sitra Land Vibroseis. Shell publication, 41P.

Tiab, D., and Donaldson, E. C. (2015): Theory and practice of measuring reservoir rock and fluid transport properties. Gulf Prof. Publ., Waltham, MA, USA, 819 P. 
3D seismic interpretation and structural analysis of Sitra-8 field

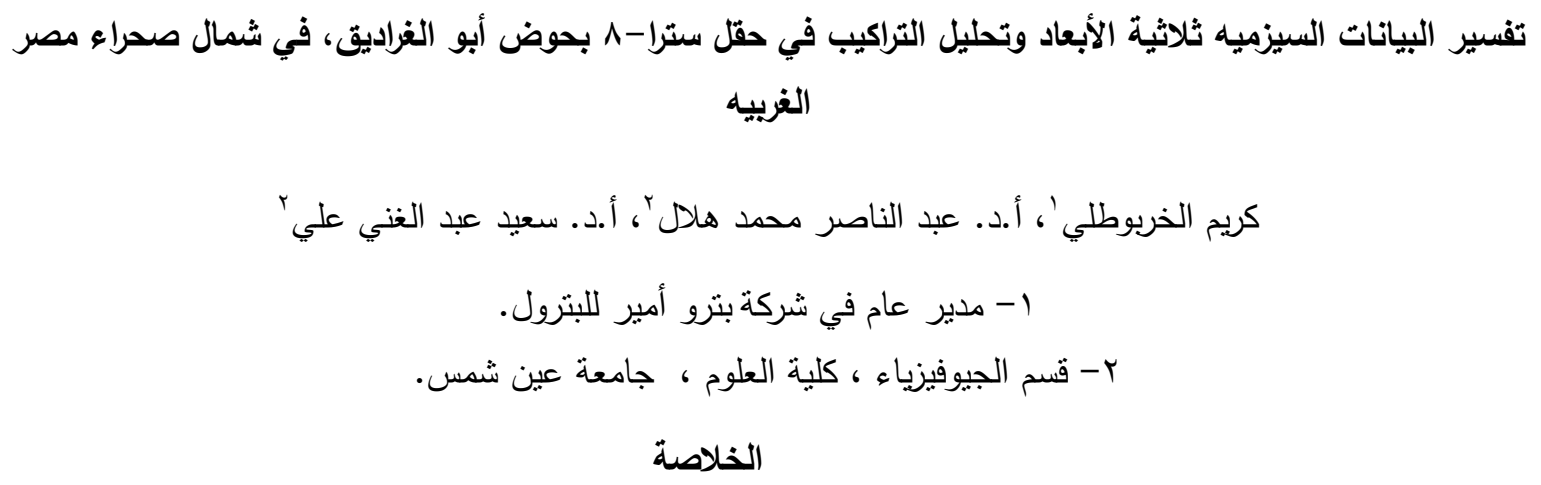

يمتاز حقل سترا ^ في شمال الصحراء الغربيه بأنه متعدد النطاقات الخزانيه ـ والمشكله الحقيقيه في هذه المنطقه أن هناك آبار مياه وآبار جافه من المفترض أن تتتج الزيت. الدراسات التكامليه بين البيانات التركيبيه الناتجه عن تحليل البيانات السيزميه

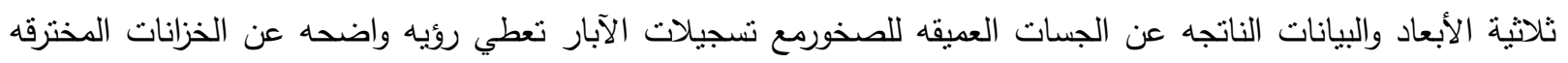

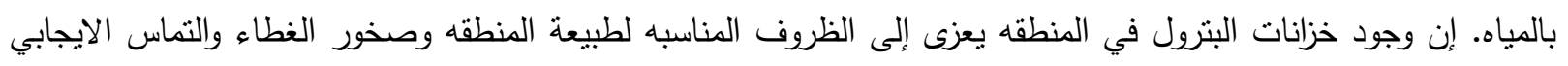

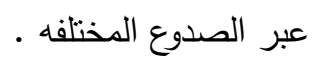
وتقترح الدراسه الحاليه تكامليه مهمه بين البيانات الجيولوجيه التحت سطحيه والبيانات السيزميه المفسره ثلاثية الأبعاد وتسجيلات الآبار المختلفه بغرض تحديد التراكيب التحت سطحيه المؤثره وتقيم الخزان في منطقة سترا-1 بشمال الصحراء الغربيه بمصر. وذللك من الممكن أن يخدم في أي عملية تطوير مستقبلي وتوسيع الحفر والتي ستتعكس بدورها اقتصاديا على بنى المنطقه . المعند

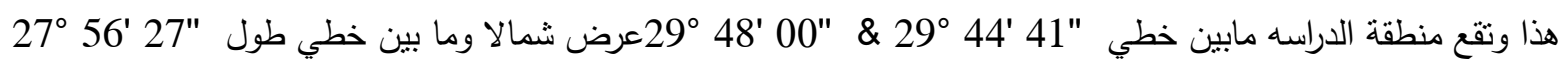

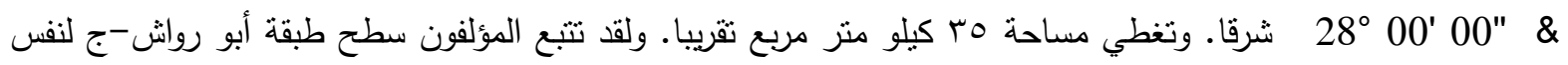

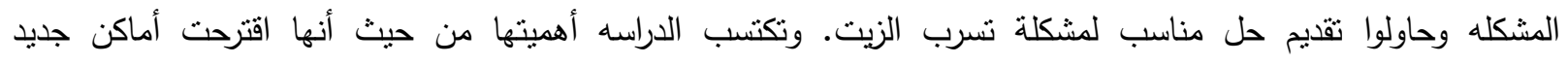
للحفروالاستكثاف. ويقترح مؤلفوا الدراسه الحفر في الجزء الثمالي الغربي من منطقة الدراسه بهدف نطوير الحقل مستقبليا. 